\title{
LIBERTAD DE EXPRESIÓN, Y EQUIDAD, EN LAS CAMPAÑAS ELECTORALES. NUEVOS DESARROLLOS
}

\author{
Ignacio TORRES MURO ${ }^{1}$
}

\section{Sumario:}

I. Algunas explicaciones previas

II. La libertad de expresión, especialmente en campañas electorales, como instrumento básico del Estado democrático

III. ¿Es distinto el régimen de la libertad de expresión en los procesos electorales?

IV. Métodos de control de la libertad de expresión en la campaña electoral

V. Algunas respuestas de la práctica española a los problemas de libertad de expresión en las campañas electorales

VI. Nuevos desarrollos en la jurisprudencia electoral mexicana

VII. Conclusión. ¿Puede sacarse partido a la "equidad" y a la "igualdad de oportunidades" en materia electoral?

VIII. Fuentes consultadas

\section{ALGUNAS EXPLICACIONES PREVIAS}

Quien aborde la, sin duda, esforzada, y, por otra parte, - un poco absurda - tarea de leer lo que sigue, debe saber que el texto con el que se enfrenta es el último episodio por ahora, de una dedicación -tampoco excesiva, debo decir - a reflexionar sobre el problema de la libertad de expresión en las campañas electorales, ${ }^{2}$ y sus consecuencias

\footnotetext{
${ }^{1}$ Catedrático de Derecho constitucional de la Universidad Complutense de Madrid, del Cuerpo de Letrados del Tribunal Constitucional.

${ }^{2}$ Sobre éstas, en general, y a pesar de los años transcurridos, véanse, López Guerra, Luis, Las campañas electorales en Occidente, Barcelona, Fundación Juan March-Ariel, 1977; una síntesis en García Soriano, María Vicenta, Elementos de derecho electoral, Valencia, Tirant lo Blanch, 1999, pp. 99 y ss.
} 
Este obra forma parte del acervo de la Biblioteca Jurídica Virtual del Instituto de Investigaciones Jurídicas de la UNAM www.juridicas.unam.mx

DOI: http://dx.doi_org/10.22201/iij.24487910e_2016.9.10094

para la deseable equidad de los procesos de ese tipo.

Todo empezó cuando al autor de estas líneas le invitaron, sin demasiado fundamento, ya que no era un especialista en la materia, a hablar sobre este asunto en el I Seminario Internacional del Observatorio Judicial Electoral, celebrado bajo el auspicio del Tribunal Electoral del Poder Judicial de la Federación mexicana, allá por el 2008. Como soy un académico medianamente responsable preparé una intervención más o menos aseada, que, posteriormente, revisé como consecuencia del debate que se produjo en aquel acto.

No es difícil recordar que se trataba de uno de los tópicos en los que las discusiones eran más duras, como consecuencia de lo que había ocurrido en las elecciones presidenciales de 2006 (la famosa "propaganda negra") y de la crítica a las decisiones del TEPJF, por cierto, muy polémicas, producto de los recursos contra los resultados oficiales de las mismas.

Hijo de todos esos esfuerzos fue un texto publicado en 2010, en el que recogía mis ideas hasta ese momento, confrontando un repaso a la doctrina europea, pues no en vano mi formación es preferentemente "eurocéntrica", con las principales sentencias mexicanas, en lo que, evidentemente, era una aproximación al asunto de cierta utilidad pero también algo limitada. ${ }^{3}$

Tiempo después se han producido dos circunstancias venturosas. La primera, y más importante, fue la de una investigadora mexicana, Yessica Esquivel, que sin duda mal aconsejada comenzó a preparar su tesis doctoral, conmigo como director sobre este tema.

Suele ocurrir - creo que nos pasa a todos los que supervisamos trabajos de este tipo- que pasados los primeros compases de la relación en los que uno aún puede enseñar algo, empieza, el que supuestamente dirige, a aprender, y mucho de la doctoranda que está al pie del cañón haciendo el análisis en profundidad. Esto, sin duda, me está pasando con ella.

Por otra parte, ha sucedido también que mis amigos mexicanos, y españoles, aún no se han dado cuenta de mi mediocridad, tantas veces demostrada, $y$, persistentes en el

\footnotetext{
${ }^{3}$ Torres Muro, Ignacio, “La libertad de expresión en las campañas electorales y sus límites. Propaganda negativa. Problemas y controles", en Ríos Vega, Luis Efrén (coord.), Tópicos contemporáneos de derechos políticos fundamentales, Madrid, Dykinson, 2010.
} 
Este obra forma parte del acervo de la Biblioteca Jurídica Virtual del Instituto de Investigaciones Jurídicas de la UNAM www.juridicas.unam.mx

error, siguen invitándome a dar charlas y cursos en México. La última vez, sobre este tema, en febrero de 2013 en el TEPJF. De nuevo, entre otras cosas, para hablar sobre libertad de expresión, y equidad en campañas electorales. Consecuencia de esta última estancia, es la idea de los organizadores de la misma, de publicar los textos allí apuntados. A mí me corresponde al parecer, decir algo interesante sobre el asunto que intermitentemente me ocupa desde hace tiempo.

Debo aclarar, por tanto, al amable lector, que no voy a repetir lo que expuse en Torres Muro - ya citado- pero si voy a hacer frecuentes remisiones a dicho texto. Lo novedoso del que presento ahora es una revisión de la jurisprudencia más reciente, y la incorporación de algunos materiales teóricos, o publicados hace poco, o que no manejé en su momento de cierto interés.

Todo ello, tengo que confesarlo, es el resultado de una relación fluida con la doctoranda citada, ${ }^{4}$ y, cómo no, del debate que se produjo una vez más en dicha estancia en México, con quienes están trabajando sobre el terreno en estas materias (abogados, colaboradores del TEPJF, políticos, etcétera). De ellos aprendo cada día la necesidad de revisar mis concepciones teóricas fuertemente ligadas, como no podía ser de otro modo, a la realidad europea que es en la que vivo y en la que desarrollo mis principales investigaciones, al contrastarlas con la mexicana en particular, y la iberoamericana en general.

Suelo decir que las invitaciones a viajar a países de más allá del charco, en las que se supone que voy a enseñar algo, se saldan con resultados que me favorecen. Cuento cómo van las cosas en Europa, lo que frecuentemente es de escasa utilidad para los que me oyen. Lo curioso es que aprendo mucho más de lo que enseño, hablando con los especialistas latinoamericanos o escuchando sus objeciones a los pueriles intentos, tan habituales, de trasladar nuestras categorías y soluciones al llamado pomposamente "Nuevo Mundo". Algunos se escandalizan de esto que digo o lo atribuyen a la coquetería habitual en los vanidosos profesores universitarios: se equivocan. Lo digo porque lo creo firmemente, y el texto que sigue es un ejemplo más de esa convicción.

En este contexto siempre me ha resultado interesante el caso mexicano, en el que existe una intención decidida de llegar a elecciones que la Constitución de ese país

\footnotetext{
${ }^{4}$ El último texto inédito que me ha facilitado, lo citaré como Esquivel, Yessica, Libertad de expresión en campaña electoral, 2013.
} 
Este obra forma parte del acervo de la Biblioteca Jurídica Virtual del Instituto de Investigaciones Jurídicas de la UNAM www.juridicas.unam.mx

define como "auténticas" (artículo 41, CPEUM). Estas aspiraciones que son comunes en el contexto iberoamericano, tras mucho tiempo de farsas sostenedoras de determinadas oligarquías, llevan a diseñar normativas, al respecto, de gran complejidad. Una complejidad, por cierto, ineludible en países con poblaciones numerosas, distribuidas en un territorio amplio y con características socioeconómicas muy diversas.

Sobre la imposibilidad, en tales contextos, de lograr el objetivo de procesos electorales, no ya "auténticos" sino "perfectos" (que no existen, por otra parte, sobre la faz de la tierra) ya me he extendido en otra publicación, en la que abordaba el tema de la supuesta financiación ilegal de las elecciones presidenciales de 2012 y la respuesta del TEPJF. ${ }^{5}$

Basta por ahora con decir que, también en el campo de la libertad de expresión en campañas electorales, a lo más que podemos aspirar es a corregir los defectos claros en la configuración de la misma, y a tener por norte —en la regulación jurídica- el ideal inalcanzable de que el flujo de ideas e informaciones, sea completamente fluido y respetuoso con los derechos de todos.

Otro dato general, no menos importante, que es necesario tener presente es que a partir de la reforma constitucional mexicana de 2011, y la apertura al derecho internacional de los derechos humanos de la ley fundamental, las normas en presencia son variadas y de orígenes muy diversos. Esto hace que fijar con claridad cuáles son las vigentes, en nuestra materia, no resulte en absoluto fácil. Por lo que, lo ha empezado a intentar el TEPJF, y sus decisiones deberán ser tenidas muy en cuenta. ${ }^{6}$

Aclaradas estas cosas, podemos pasar al bloque de mi estudio.

\section{LA LIBERTAD DE EXPRESIÓN, ESPECIALMENTE EN CAMPAÑAS ELECTORALES, COMO INSTRUMENTO BÁSICO DEL ESTADO DEMOCRÁTICO}

Antes de entrar al análisis de problemas concretos, y para que el asunto quede razonablemente centrado, es preciso revisar algunas de las verdades elementales

\footnotetext{
${ }^{5}$ Torres Muro, Ignacio, “La supuesta financiación ilegal, en las presidenciales mexicanas de 2012, ante el Tribunal Electoral del Poder Judicial de la Federación", en Molina Piñeiro, l., Ojesto Martínez Porcayo, J. F et al., Las elecciones presidenciales 2012, Toluca, Estado de México, UNAM, IEEM, COPUEX, 2013, pp. 1195 y ss.

${ }^{6}$ Por todas, sentencia SUP-JIN-359; pp. 39 y ss., ibidem, pp. 1178 y 1179.
} 
Este obra forma parte del acervo de la Biblioteca Jurídica Virtual del Instituto de Investigaciones Jurídicas de la UNAM www.juridicas.unam.mx

relativas a la libertad de expresión, en general, y a la misma en las campañas electorales. Solamente quiero recordar, a quien pueda haberlo olvidado, que la primera es un elemento central en todo Estado democrático, y uno de los datos que nos permiten diferenciar un sistema verdaderamente constitucional de las muchas engañifas normalmente plebiscitarias o "caudillistas", que en nuestros días se presentan como alternativa a las soluciones clásicas; la segunda verdad es que la libertad de expresión en las campañas, por su parte, es un rasgo básico de las que se han dado en llamar "elecciones libres" o "competitivas".

Las mismas se caracterizan porque se desarrollan en un contexto democrático en el que están presentes "la competencia política, el derecho a la oposición, elecciones libres periódicas y derechos fundamentales constitucionalmente garantizados".

En ellas entran en juego "la libertad de candidatura electoral", "la competencia entre candidatos", "la igualdad de oportunidades... especialmente en el campo de la propaganda electoral", el "voto secreto" como garantía de la "libertad de elección", un "proceso electoral que deja la decisión electoral al buen criterio del elector", y el carácter revocable de la decisión electoral en elecciones posteriores. ${ }^{7}$

Como imaginará quien lea esto sobre la importancia de la libertad de expresión y la necesidad de un reconocimiento lo más amplio posible de la misma, para que podamos hablar de Estado democrático han corrido ríos de tinta. ${ }^{8}$

Es posible, en este punto, remitirse a Carbonell, que al hablar de las justificaciones de la misma hace una buena síntesis y se refiere a los argumentos del descubrimiento de la verdad, de la autorrealización y de la participación democrática. ${ }^{9}$

No caben dudas al respecto. Desde el momento en que los sistemas constitucionales se basan en la libre crítica de quienes ejercen el poder, de modo que se puedan construir alternativas a los mismos, con el objetivo de que la circulación de las élites, y las posibles rectificaciones de las políticas públicas se construyan sin problemas, está claro que es

\footnotetext{
${ }^{7}$ Nohlen, Dieter, Sistemas electorales del mundo, Madrid, CEC, 1981, p. 23. Una visión anglosajona e interesante, Barendt, Eric, Freedom of Speech, Clarendon Press, Oxford, 2007, 1987, pp. 2 y ss.

9 Carbonell, Miguel, La libertad de expresión en materia electoral, México, TEPJF, 2008, pp. 15-27.
} 
Este obra forma parte del acervo de la Biblioteca Jurídica Virtual del Instituto de Investigaciones Jurídicas de la UNAM

preciso que los canales de comunicación de hechos e ideas sean lo más abiertos que se pueda.

Para apoyar la idea de la "fundamentalidad" de la libertad de expresión podría traer en mi auxilio, numerosas citas de autoridades académicas. Me van a permitir, sin embargo, que me deje llevar por la inclinación habitual del funcionario -en mi caso, aunque en excedencia, del Tribunal Constitucional español, en adelante TC español- y recurra únicamente a citar el fundamento jurídico 4 , de una de sus decisiones (STC 20/1990, del 15 de febrero), en el que, resumiendo la doctrina que ya había sentado en otras anteriores, afirma tajantemente que: "las libertades del artículo 20 (de la Constitución española; expresión e información, se entiende) no son sólo derechos fundamentales de cada ciudadano sino que significan el reconocimiento y la garantía de una institución política fundamental, que es la opinión pública libre, indisolublemente ligada con el pluralismo político que es un valor fundamental y un requisito del funcionamiento del Estado democrático... El artículo 20 de la CE... garantiza el mantenimiento de una comunicación pública libre, sin la cual quedarían vaciados de contenido real otros derechos que la Constitución consagra reducidas a formas hueras las instituciones representativas y absolutamente falseado el principio de legitimidad democrática... que es la base de toda nuestra ordenación jurídico-política".

No conviene olvidar, sigue diciendo el TC español, que "para que el ciudadano pueda formar libremente sus opiniones y participar de modo responsable en los asuntos públicos ha de ser también informado ampliamente de modo que pueda ponderar opiniones diversas e incluso contrapuestas".

En otra de sus sentencias importantes en esta materia (STC 85/1992, del 8 de junio, FJ 4), nos recordará, por otra parte, que dichas libertades del artículo 20, CE, "además de derechos fundamentales, son valores objetivos esenciales del Estado democrático y, como tales, están dotados de valor superior o eficacia irradiante" que justificaría la particularidad del "juicio ponderativo" que conduce a apreciar si hay lesión de otros derechos (honor, principalmente) y, si incluso cuando dicha lesión exista, "viene o no justificada por el valor prevalente de tales libertades".

En los textos anteriores existen numerosas influencias (del Tribunal Supremo norteamericano, de otros tribunales constitucionales, y del Tribunal Europeo de Derechos Humanos, por ejemplo) de modo que su originalidad es relativa. Nunca la ha 
Este obra forma parte del acervo de la Biblioteca Jurídica Virtual del Instituto de Investigaciones Jurídicas de la UNAM www.juridicas.unam.mx

pretendido el TC español que tiene por costumbre beber en todo tipo de fuentes, jurisprudenciales, y académicas, antes de abordar la resolución de un problema.

Por lo que en estas sentencias se condensa una larga tradición de muy diversos órganos jurisdiccionales, y de constitucionalistas de todo tipo. Referirnos a todos sus matices nos llevaría más espacio del que disponemos. Recuérdese que, aquí lo único que se pretende es afirmar con claridad la idea de que la libertad de expresión es un elemento básico del Estado constitucional. En las realidades políticas en donde se recorta o no se reconoce en toda su amplitud, estaremos, sin duda alguna, hablando de un sistema autoritario o totalitario. A estos modestos efectos, creo que basta con la cita que se acaba de hacer de los extractos más significativos de la doctrina del Tribunal Constitucional español.

La segunda idea previa sobre la que gustaría llamar la atención y de la que también tendré que hacer unas reflexiones casi telegráficas, es la de que si la libertad de expresión es básica para el funcionamiento del Estado democrático; como acabamos de ver en los procesos electorales - tan importantes en este tipo de organizaciones políticas, entre otras cosas porque en ellos se decide quien ha de ocupar muchos de los cargos públicos- este derecho fundamental tiene tanta trascendencia que lo constituye en uno de los rasgos fundamentales de las llamadas "elecciones libres", en el sentido en el que se ha trabajado sobre este concepto, sobre todo en la jurisprudencia del Tribunal de Estrasburgo (artículo 3o., del protocolo adicional al Convenio Europeo de Derechos Humanos).

Como se ha dicho, "el deber de los Estados de organizar elecciones libres protege el ejercicio de la libertad de expresión de los electores en la elección de la legislatura. No se pueden separar ambos polos: elecciones libres y libertad de expresión; hasta el punto de 
Este obra forma parte del acervo de la Biblioteca Jurídica Virtual del Instituto de Investigaciones Jurídicas de la UNAM www.juridicas.unam.mx

que la libertad de expresión forma parte de la garantía". ${ }^{10}$

Recuérdese por otra parte, que el texto del Protocolo europeo sostiene que se trata de que se den "las condiciones que garanticen la libre expresión de la opinión del pueblo en la elección del cuerpo legislativo". Sin libre circulación de ideas en la campaña, está claro que los electores no tomarán sus decisiones de una manera propia de un régimen político verdaderamente democrático.

Como me ha ocurrido más arriba, la cita de autoridades sobre esta idea, requeriría el espacio de una monografía, de modo que recurriré a la doctrina del Tribunal Constitucional español, de nuevo basada en tradiciones jurisprudenciales, y académicas, muy variadas, pero que son unánimes en cuanto al reconocimiento de que nos encontramos ante un elemento básico en los procesos electorales de un sistema político democrático.

Así, en la STC 136/1999 del 20 de julio, nos dice que: "los derechos de participación en los asuntos públicos (artículo 23.1, CE) y de acceso a los cargos públicos (artículo 23.2, CE)... poseen no sólo un contenido prestacional y una función de garantía de institutos políticos, como el de la opinión pública libre, sino también un contenido de derecho de libertad que se concreta, en lo que aquí interesa, en la posibilidad constitucionalmente protegida de ofrecer a los ciudadanos sin interferencias o intromisiones de los poderes públicos, los análisis de la realidad social, económica o política y las propuestas para transformarla que se consideren oportunas".

Dicho con brevedad, unas elecciones en las que no se respete exquisitamente la libertad de expresión, en cuanto ésta contribuye, de manera decisiva, al establecimiento de un debate público que puede orientar a los electores sobre cuál debe ser el sentido de su voto, no son elecciones libres.

10

García Roca, Javier, “Del compromiso internacional de los Estados de organizar elecciones libres al derecho de sufragio de los ciudadanos (artículo 3 P1)", en García Roca, J. y Santolaya, P. (coords.), La Europa de los derechos: el Convenio Europeo de Derechos Humanos, 2da. ed., Madrid, Centro de Estudios Políticos y Constitucionales, 2009, p. 906.

Sobre la jurisprudencia del TEDH acerca de los derechos electorales véase, Martín-Retortillo Baquer, Lorenzo, "Los derechos electorales a la luz de la jurisprudencia del Tribunal Europeo de Derechos Humanos", en Pascua Mateo, Fabio (dir.), Estado democrático y elecciones libres: cuestiones fundamentales de derecho electoral, Asamblea de Madrid, Thomson-Civitas, 2010. 
Este obra forma parte del acervo de la Biblioteca Jurídica Virtual del Instituto de Investigaciones Jurídicas de la UNAM www.juridicas.unam.mx

Por tanto, pueden contribuir a operaciones de maquillaje de regímenes autoritarios y totalitarios, siempre prestos a simular una legitimidad democrática de la que carecen pero se encuentran completamente al margen de lo propio de un sistema constitucional, por mucho que algunos se hayan empeñado en los últimos tiempos en pretender que creamos que esas son cuestiones de detalle que no vician en absoluto sus intentos de presentarse como una continuación lógica del movimiento constitucional adaptado a nuevas realidades.

Todas las posturas respecto a la configuración de los regímenes políticos pueden ser respetables, y los democráticos no están, -eso es evidente- exentos de defectos, aunque lo que no podemos hacer es comulgar con ruedas de molino, y reconocer como Estados constitucionales a sistemas que no lo son. Y ello no sólo por razones ideológicas, terreno más bien resbaladizo, sino por un mínimo de seriedad científica.

Habiendo, como hay muchos otros criterios, para concluir que nos hallamos ante un sistema constitucional, los dos problemas en los que nos hemos detenido son esenciales. Sin libertad de expresión no puede construirse un régimen democrático. También debe quedar claro que las elecciones libres son básicas en este tipo de realidades. Uno de los elementos que las distinguen de las farsas plebiscitarias a las que algunos nos tienen acostumbrados, es la existencia de una regulación equilibrada de los problemas de la libertad de expresión. Esta tarea no es fácil pero hay que partir de la base de que sin dicha libertad, las elecciones se convierten en un modo inadecuado de contestar a la pregunta básica que se plantea en todas las democracias, y se responde a través de esos procesos: nada menos que fijar quiénes deben hacerse con el poder político en disputa, y qué intervenciones en la vida social podrán llevar a cabo desde el mismo.

Está claro que también en estos terrenos podemos encontrarnos con problemas de colisión con otros derechos o regulaciones. Es interesante como se han abordado los mismos en la jurisprudencia del Tribunal Europeo de Derechos Humanos, en donde se han presentado casos en los que ha habido que controlar, por ejemplo, la previsión de límites desproporcionados a los gastos de particulares para la realización de campañas paralelas en los periodos electorales. ${ }^{11} \mathrm{O}$ el hecho de que se impongan limitaciones a la libertad de expresión a determinados funcionarios públicos en el marco de procesos

${ }^{11}$ Bowmam vs. Reino Unido, del 19 de febrero de 1998. 
Este obra forma parte del acervo de la Biblioteca Jurídica Virtual del Instituto de Investigaciones Jurídicas de la UNAM www.juridicas.unam.mx https://biblio.juridicas.unam.mx/bjv https://revistas.juridicas.unam.mx/

DOI: http://dx_doï.org/10_22201/iij_24487910e_2016.9.10094

electorales. ${ }^{12}$ En todos los supuestos ha quedado claro que las restricciones a la libertad de expresión, sobre todo aquellas que puedan afectar a una campaña electoral, recortando los debates, y la contienda planteada en buena lid, han de ser vistas con sospecha.

\section{III. ¿ES DISTINTO EL RÉGIMEN DE LA LIBERTAD DE EXPRESIÓN EN LOS PROCESOS ELECTORALES?}

Bastará en el contexto de este artículo con recordar, como siempre, que la libertad de expresión es uno de los más clásicos ejemplos de derecho fundamental que conoce diversos límites, derivados de la colisión con otros derechos, y del necesario respeto a determinadas exigencias, y valores propios de las sociedades democráticas.

Cabe señalar, que no voy a repetir lo dicho en esta materia, razonablemente compleja, en otras sedes. Permítaseme la remisión a un trabajo anterior ${ }^{13}$ de modo que quede, sin más, sentada esta premisa para lo que sigue.

También conviene tener en cuenta que la libertad de expresión se proyecta en diversos órdenes de la vida social y, más en concreto, constitucional. Está claro que esos diferentes contextos modulan las reglas del ejercicio de la misma.

Por ejemplo, siempre se han distinguido entre las críticas a las personas con proyección pública, y aquellas que se refieren a personas anónimas que no han entrado, muchas veces con acierto, en determinados juegos mediáticos, teniendo estos últimos, un ámbito de vida privada más amplio que el de quienes, por los cargos que ejercen o por la propia voluntad, se mueven en el complejo terreno de lo abierto al escrutinio de toda la ciudadanía, desde el momento en que se trata de espacios comunes a todos.

Uno de los espacios tradicionales, en los que está expresamente prevista una libertad irrestricta, es el de las cámaras legislativas, ya que como no podía ser menos, en casi todos los sistemas democráticos, existe un claro interés en que en el Parlamento se produzcan debates interesantes y fructíferos. Sin esa libertad no estaríamos hablando de

12

Ahmed y otros vs. Reino Unido, del 2 septiembre de 1998, véase, Bustos Gisbert, Rafael, “Los derechos de libre comunicación en una sociedad democrática (artículo 10 CEDH), en García Roca, J. y Santolaya, P. (coords.), La Europa de los derechos: el Convenio Europeo de Derechos Humanos, 2da.ed., Madrid, Centro de Estudios Políticos y Constitucionales, 2009, p. 626.

${ }^{13}$ Torres Muro, Ignacio, “La libertad de expresión..., cit., pp. 130 y ss. 
Este obra forma parte del acervo de la Biblioteca Jurídica Virtual del Instituto de Investigaciones Jurídicas de la UNAM www.juridicas.unam.mx https://biblio.juridicas.unam.mx/bjv

unos verdaderamente serios y respetables.

Nos referimos a la prerrogativa de la inviolabilidad, con una tradición acrisolada (artículo 9o. Bill of Rights inglés: "That The Freedome of Speech and Debates or Proceedings in Parliament ought not be impeached or questioned in any Court or Place out of Parliament", "que la libertad de expresión y debates o procedimientos en el Parlamento no debe ser controlada o cuestionada en ningún Tribunal o lugar fuera del Parlamento", nada menos que de 1689), que se encuentra recogida en multitud de textos constitucionales (desde luego, el mexicano -artículo 61, CPEUM- y el español artículo $71, \mathrm{CE}-$ ).

En este tema es cierto, por otra parte, que lo que se hace es excluir la intervención de los tribunales ordinarios, ante posibles denuncias de excesos en la materia pero siempre hay que recordar que uno de los objetivos del sistema de disciplina parlamentaria, ${ }^{14}$ administrado por los órganos de gobierno de las Asambleas (presidentes, y mesas), es evitar que, en ese ámbito, se produzcan supuestos de uso abusivo de la libertad de expresión.

Nos hallamos, por tanto, más en un caso en el que se les confía a las autoridades de la Cámara el control de estos problemas, que ante una situación de falta de reglas al respecto. ${ }^{15}$

Pero lo que nos interesa en este estudio, es reflexionar sobre si las normas que regulan la libertad de expresión deben ser diferentes en los procesos o campañas electorales. Por una parte, parece evidente que una manera de aproximarse más relajada a los problemas que pueden causar determinados excesos, podría encontrar una justificación en la idea de que cuando nos referimos a elecciones, estamos hablando de una batalla en la que quizás convenga que los límites a aquel derecho sean menos estrictos. El fin, de esa actitud, consistiría en fomentar una verdadera

14 Matheus Fernández, Juan Miguel, La disciplina parlamentaria, Zaragoza, Fundación Manuel Giménez Abad, 2013.

15

Sobre la inviolabilidad el análisis más extenso, en castellano, es el de Mancisidor Ataraz, Eduardo, La prerrogativa constitucional del inviolabilidad parlamentaria, Oñati, IVAP, 2009; un ejercicio de comparación -Reino Unido, Países Bajos y Francia - en Hardt, Sacha, Parliamentary Immunity, Intersentia, Cambridge, Antwerp, Portland, 2013. 
Este obra forma parte del acervo de la Biblioteca Jurídica Virtual del Instituto de Investigaciones Jurídicas de la UNAM www.juridicas.unam.mx

competencia entre los actores políticos, que deben entender que sus propuestas tienen que ser sometidas a críticas que, a lo peor, son especialmente duras o acerbas. Como se ha señalado "el escenario que propicia la campaña electoral dota de mayor flexibilidad a los límites de la libertad de expresión, con el objeto de permitir un debate libre y abierto". ${ }^{16}$

Sin embargo, por otro lado hay quien sostiene que el principal objetivo de la campaña electoral es ayudar a los ciudadanos a formar un criterio bien fundamentado antes de ejercer su derecho al voto, tanto sobre las propuestas de los partidos como sobre si los equipos de personas que presentan como candidatos serán capaces de llevar esas ideas a cabo. Para ello, es imprescindible que nos hallemos ante una campaña lo más "limpia" posible, en la que los votantes observen cómo les son presentadas las diversas alternativas entre las que pueden elegir, sin que en el debate sobre las mismas en el que pueden participar todo tipo de actores políticos y sociales, además de los llamados líderes de opinión, se cuelen argumentaciones rastreras, insultantes, o simplemente engañosas.

El lector se habrá dado ya cuenta de que en los dos párrafos anteriores he presentado, más que dos alternativas reales, lo que en la sociología de Max Weber se denominan "tipos ideales", teóricamente muy útiles para sintetizar la explicación de un problema, pero que, con toda evidencia, nunca aparecen así de "puros" en las regulaciones de las campañas electorales en los países democráticos. ${ }^{17}$

Si se me permite referirme al modelo español, que es el que conozco, diré que nuestra Ley Orgánica de Régimen Electoral General (la llamada LOREG), prevé especialidades en los instrumentos clásicos con los que se matiza la libertad de expresión.

Por ejemplo, en su artículo 68, sobre el derecho de rectificación (llamado

\footnotetext{
${ }^{16}$ Esquivel, Yessica, op.cit., p. 42.

17

Sobre el concepto de "tipo ideal" en Max Weber, de la ingente bibliografía, cabe remitir a Vincent, Jean Marie y Weber, Max, "La metodología de Max Weber" y “Fundamentos metodológicos de la sociología”, Barcelona, Anagrama, 1972, pp. 17, 35, 71 y ss; Weber, Max, Economía y sociedad, México, Fondo de Cultura Económica, 1992, pp. 16 y ss.; Weber, Max, "La <<objetividad>> cognoscitiva de la ciencia social y de la política social", en Weber, Max, Ensayos sobre metodología sociológica, Buenos Aires, Amorrortu, 2001, pp. 79 y ss.
} 
Este obra forma parte del acervo de la Biblioteca Jurídica Virtual del Instituto de Investigaciones Jurídicas de la UNAM www.juridicas.unam.mx

habitualmente en México derecho de réplica), dispone que la misma debe ser publicada en otro medio, "de la misma zona y de similar difusión", y a costa del infractor, si el que cometió la infracción tiene una periodicidad de más de tres días, que no permite que la respuesta se produzca a tiempo (artículo 68.1, LOREG).

Por otra parte, reduce —drásticamente - los plazos del correspondiente juicio verbal, de manera que la decisión llegue todavía con más celeridad. Deberá celebrarse, en estos casos de rectificación en el marco de una campaña electoral, dentro de los cuatro días de la petición, al juzgado, de que obligue al renuente a publicar el texto correspondiente, en el que es necesario limitarse a rectificar "los hechos de la información" que se considera inadecuada (artículo 20. de la Ley Orgánica 2/1984, del 26 de marzo, reguladora del derecho de rectificación).

Hay que recordar que la regulación general (Ley Orgánica) prevé un sistema ya muy ágil, en el que se comienza con la remisión del escrito de rectificación en un máximo de siete días naturales (artículo 2o.). Su publicación o difusión radiofónica o televisiva debe producirse en tres días, si lo permite la periodicidad del medio (artículo 3o.).

Cuando nos encontramos con una negativa para publicar la rectificación, son siete días hábiles para ejercitar ante el juzgado, la "acción de rectificación" (artículo 40.). El juez convocará, telegráficamente, dentro de los siete días siguientes al juicio verbal, especialidad de los juicios civiles especialmente sumaria (artículos 437-447, de la Ley $1 / 2000$ del 7 de enero, del enjuiciamiento civil).

En el mismo día o al siguiente, se dictará sentencia (artículo 6o., c). ${ }^{18}$

No olvidemos que dicho derecho en México se denomina de "réplica", y está reconocido constitucionalmente, con el lógico laconismo (artículo 60., CPEUM; "el derecho de réplica será ejercido en los términos dispuestos por la ley"). Se trata de una prueba de que entre nuestros dos países, existe lo que los británicos, y norteamericanos denominan el caso de las naciones "separadas por un mismo idioma" ("two countries separated by the same language"; frase atribuida a Oscar Wilde, George Bernard Shaw, y

18

Sobre el derecho de rectificación, en España, y en perspectiva comparada —Unión Europea y USA一, véase Farré López, Pedro, El derecho de rectificación. Un instrumento defensa frente al poder de los medios, La Ley, Las Rozas de Madrid, 2008; respecto a la rectificación en procesos electorales, pp. 427 y ss.; también estudia esta regulación, García Soriano, María Vicenta, Jueces y magistrados en el proceso electoral, Madrid, CEPC, 2000, pp. 208-222. 
Este obra forma parte del acervo de la Biblioteca Jurídica Virtual del Instituto de Investigaciones Jurídicas de la UNAM www.juridicas.unam.mx

Winston Churchill, sin pruebas definitivas en ningún sentido).

Lo digo porque en España la réplica supone la posibilidad de discutir argumentos, y no sólo hechos, como en el caso de la rectificación (el supuesto más claro es el derecho de réplica en un debate parlamentario), y entiendo que la "réplica" mexicana es algo análogo a nuestra "rectificación".

En ésta, recordemos una vez más, de lo que se trata es de corregir una versión de los hechos que no se ajusta a la realidad pero sin hacer comentario alguno sobre las opiniones que hayan podido expresarse. La falta de regulación legal en México, lamentada por muchos, ${ }^{19}$ y calificada de "asignatura pendiente con los mexicanos" que tiene el Congreso de la Unión, ${ }^{20}$ limita las posibilidades de comparar las normativas.

Asimismo, en el artículo 148, de la LOREG española, nos encontramos con la regla de que "cuando los delitos de calumnia e injuria (los clásicos en el régimen penal de la libertad de expresión) se cometan en el periodo de campaña electoral y con motivo u ocasión de ella, las penas privativas de libertad previstas al efecto en el Código Penal se impondrán en su grado máximo". Como puede verse en los artículos 206 y 209 de dicho Código, las penas correspondientes van de tres a siete meses de prisión -injurias sin publicidad-a seis meses a dos años - calumnias - pasando por la pena de seis a catorce meses de las injurias con publicidad.

Lo importante en todo caso es que para el legislador español, las actividades consistentes en "la imputación de un delito hecha con conocimiento de su falsedad o temerario desprecio hacia la verdad" (calumnia; artículo 205, CP), y en "la acción o expresión que lesionan la dignidad de otra persona, menoscabando su fama o atentando contra su propia estimación" (injuria; artículo 208, CP), son especialmente inadmisibles durante la campaña electoral. Por ello, las penas que las castigan deben tener una mayor duración. De este modo, quien cometa estos delitos sabe que se enfrentará a una reacción aún más dura de la habitual, y probablemente pensará antes de realizar determinadas conductas.

19

Astudillo, César et al., “La libertad de expresión y sus principales manifestaciones en el contexto de la democracia electoral mexicana", Revista Mexicana de Derecho Electoral, núm. 4, 2013, pp. 213 y ss.

20

Calleja Gutiérrez, Aleida Elsi et al., “Perspectivas y evolución del modelo de comunicación político electoral", Revista Mexicana de Derecho Electoral, núm. 4, 2013, p.242. 
Este obra forma parte del acervo de la Biblioteca Jurídica Virtual del Instituto de Investigaciones Jurídicas de la UNAM www.juridicas.unam.mx

El buen funcionamiento de ambas soluciones está conectado en España, con toda evidencia, con la agilidad en la respuesta de los correspondientes órganos judiciales, que lo son de la jurisdicción ordinaria, penal y civil. En estos casos actúan, en el marco de procedimientos especiales, más breves, dentro de la legislación procesal general. Es fácil imaginarse el efecto disuasorio de esta normativa.

No existen entre nosotros tribunales electorales especializados, como es frecuente en Iberoamérica, con soluciones que se explican por la necesidad de responder a problemas muy diferentes de los españoles. Expongo estos ejemplos simplemente como una de esas notas de derecho extranjero que, a veces, son útiles aunque sólo sea como punto de contraste con las propias.

Volviendo a las reflexiones de tipo general, puede uno darse cuenta de que nos hallamos en un terreno en el que difícilmente se pueden hacer reglas generales previas, y en el que quizás convenga (como, por otra parte, se hace con frecuencia) dejar en manos de los tribunales la resolución de los problemas, entre otras cosas porque las circunstancias de los conflictos concretos que resuelve el Poder Judicial, ordinario o electoral, son siempre decisivas en estas materias.

También porque lo que se deduce, es que tendremos que estar continuamente intentando alcanzar un complicado equilibrio entre, por un lado, una libertad de expresión menos condicionada de lo habitual, para que los debates electorales sean más ricos, y los electores los encuentren más provechosos (en la línea de trasladar al ruedo electoral algo de lo previsto en el caso de la inviolabilidad parlamentaria); y, por otro, la exigencia de que en campaña no se utilicen trucos de "trilero" (ifuera tahúres!, por tanto), ni se descalifique al contrario, ni en resumen se incurra en actitudes que con gran plasticidad se han denominado como "propaganda negra".

Las experiencias sobre estos problemas, en los países que tienen elecciones verdaderamente libres, son innumerables, y muy complejas. Resultaría imposible en esta sede hacer referencias a todas ellas. Los que tenemos ciertos contactos con la realidad mexicana sabemos, sin embargo, que en este país el problema se presentó con toda crudeza en las elecciones presidenciales de 2006, en las que se llegó a afirmar, por algunos, que las tácticas sucias de muchos de los que intervinieron en el debate electoral, habían tenido una clara influencia sobre los resultados que finalmente se produjeron.

Acerca de que si es posible medir los efectos de la propaganda negra me pronuncié 
Este obra forma parte del acervo de la Biblioteca Jurídica Virtual del Instituto de Investigaciones Jurídicas de la UNAM

en su momento, ${ }^{21}$ encontrándome, por cierto en la buena compañía del Tribunal Constitucional español y del Tribunal Electoral del Poder Judicial de la Federación, a la hora de concluir que no parecía factible hacerlo. Eso quiere decir que las irregularidades en esta materia no pueden sostener, normalmente, un fallo de anulación de unas elecciones como pretendieron, en algún momento, determinados actores políticos.

No obstante, (y quizás precisamente por eso, porque el remedio a posteriori se presenta poco menos que imposible de articular, como acabamos de ver) es imprescindible que durante la campaña, los poderes públicos persigan las actividades de "propaganda negra", que no hacen sino envilecer la circulación libre de ideas, propia de los debates electorales, poniendo en peligro la posibilidad no tan remota como a veces se cree, de que el elector se forme antes de emitir su voto, un criterio razonablemente bien fundamentado. Pero sobre este asunto de los medios de control de la libertad de expresión en materia electoral, vamos a reflexionar en el apartado siguiente.

\section{MÉTODOS DE CONTROL DE LA LIBERTAD DE EXPRESIÓN EN LA CAMPAÑA ELECTORAL}

Aunque se pueda construir un entramado de reglas y principios, para que la libertad de expresión en las campañas electorales se ejerza de una manera equilibrada, nos queda otra tarea no menos importante: la de decidir quién ha de ser el garante de dicho orden normativo.

Somos plenamente conscientes de que como se ha dicho repetidas veces, y confirma la experiencia, los derechos fundamentales valen lo que valen sus garantías. Puede ponerse como ejemplo de hasta qué punto estamos hablando de un tópico consolidado y extendido, el hecho de que en la guía docente de la asignatura correspondiente ("El sistema de garantía de los derechos") de la Universidad Nacional de Enseñanza a Distancia española, se dice en primera frase que "los derechos fundamentales son y valen lo que valen sus garantías". ${ }^{22}$ Por ello, resulta imprescindible, también en este terreno de la libertad de expresión en los procesos en los que se seleccionan cargos públicos, establecer al lado de los reconocimientos más o menos formales, un sistema de protección de la misma, que, asimismo, sea eficaz en la corrección de los posibles

\footnotetext{
${ }^{21}$ Torres Muro, Ignacio, “La libertad de expresión..., cit., pp. 146 y ss.

${ }^{22}$ Véase, $h$ ttp://portal/uned.es
} 
Este obra forma parte del acervo de la Biblioteca Jurídica Virtual del Instituto de Investigaciones Jurídicas de la UNAM www.juridicas.unam.mx

abusos.

A nadie se le escapan las dificultades de esa tarea. A las propias de los conflictos entre la libertad de palabra e imprenta, con otros derechos fundamentales (honor, intimidad, etcétera), se añaden las derivadas de las peculiaridades de la elecciones políticas. La más importante, el hecho de que las diversas fases de las mismas (precampañas, campañas, y votaciones) se desarrollan en un periodo muy corto, en el que además asistimos a un verdadero bombardeo de mensajes. La reacción rápida y eficaz de los instrumentos de control, se hace, particularmente difícil.

Es por ello, que la respuesta es con frecuencia tardía, por lo que a los actores políticos a veces les resulta rentable incurrir en conductas inapropiadas que pudieran ser convenientes para obtener los consiguientes réditos electorales, y que sólo les serán reprochadas a toro pasado, y con unos efectos que pueden asumir como costos inevitables, siempre que las infracciones cometidas supongan una mejora en sus expectativas o han tenido una influencia notable sobre el electorado.

La regulación ideal, por tanto, es la que garantiza con respuestas rápidas y bien fundadas los equilibrios, que apuntábamos, entre los diversos derechos fundamentales en presencia; y también el respeto a otro tipo de valores e intereses. Por lo que, inmediatamente las soluciones concretas que deben adoptarse dependen, como es lógico, de las circunstancias de cada país; de una serie de datos y condicionamientos en los que hay una variedad muy grande. Van desde el tamaño del cuerpo electoral, a las tradiciones jurídicas propias, pasando por la existencia o no, de una cultura política que condiciona, cuáles son las tareas a las que debemos enfrentarnos y qué medidas corresponde aplicar.

Creo que es fácil comprender que no existe un modelo de control de las elecciones universal que se guarde, como el del metro, en el museo de pesas y medidas de París sino que cada nación debe establecer el suyo para combatir eficazmente los intentos de utilizar, en nuestro caso, y en las campañas electorales, métodos de comunicación de hechos e ideas, inadmisibles en una contienda democrática.

El único sentido que tienen las pobres reflexiones que siguen es el de examinar, desde un punto de vista teórico construido sobre diversas realidades concretas, cuáles son las posibles alternativas para resolver el dilema de quién y cómo debe ocuparse de la difícil tarea de corregir las disfunciones, en materia de libertad de expresión, en las campañas 
Este obra forma parte del acervo de la Biblioteca Jurídica Virtual del Instituto de Investigaciones Jurídicas de la UNAM www.juridicas.unam.mx

electorales.

Tampoco podemos entrar en una descripción exhaustiva de las soluciones que se dan en el planeta respecto a las diferentes administraciones electorales, tema que nos llevaría muy lejos, y que ha sido abordado por algunas, en apretada síntesis. ${ }^{23}$

O por otros, con mayores desarrollos, diferenciando entre quienes "encargan la administración de sus procesos electorales a sus órganos administrativos ordinarios"; quienes refuerzan "el funcionamiento de las instituciones con ocasión de un proceso electoral", pero sin desplazar ni al Ejecutivo ni al Judicial ordinario; los que tienen "comisiones electorales permanentes encargadas de la organización material de las elecciones", aunque sin desplazar al Poder Judicial; y por fin, quienes "sustituyen tanto al Poder Ejecutivo como al Judicial", pues suponen que "ninguna de las estructuras de poder ordinario pueden funcionar con la suficiente neutralidad y eficacia en el momento en el que se está determinando quién ocupa el poder político". ${ }^{24}$

No tendría lógica que un profesor español intentara explicar los rasgos principales de la regulación de estos asuntos en México. Me limitaré, por tanto, a decir que le llama la atención a un observador externo, la complejidad del entramado que controla las elecciones en este país: nada menos que un Instituto Federal Electoral y un Tribunal Electoral del Poder Judicial de la Federación con una Sala Superior, y cinco regionales. También, los correspondientes órganos estatales-locales que ejercen en su nivel funciones parecidas.

Se trata de uno de los ejemplos, frecuentes en Iberoamérica, de la existencia de un denominado "poder electoral", ${ }^{25}$ expresión con la que pretendemos referirnos a un

${ }^{23}$ García Soriano, María Vicenta, Elementos de..., cit., pp. 76 y 77.

24

Santolaya Machetti, Pablo, "La administración electoral”, en Álvarez Conde, Enrique (coord.), Administraciones públicas y Constitución: reflexiones sobre el XX aniversario de la Constitución española de 1978, Madrid, INAP, 1998, pp. 656-659; para mayores desarrollos véanse, Merino, Mauricio y Baños, Marco Antonio, "El servicio electoral profesional”, en Nohlen, Dieter et al. (comp.), Tratado de derecho electoral comparado de América Latina, 2da. ed., San José, Instituto Interamericano de Derechos Humanos, 2007; Jaramillo, Juan, "Los órganos electorales supremos", en Nohlen, Dieter et al. (comp.), Tratado de derecho electoral comparado de América Latina, 2a. ed., San José, Instituto Interamericano de Derechos Humanos, 2007.

25

La palabra la recoge, por ejemplo, en Santolaya Machetti, Pablo, Procedimiento y garantías electorales, 
Este obra forma parte del acervo de la Biblioteca Jurídica Virtual del Instituto de Investigaciones Jurídicas de la UNAM www.juridicas.unam.mx

nuevo supuesto sujeto en la separación clásica de poderes, dada su independencia, y el hecho de que se le encarguen, en exclusiva, determinadas atribuciones constitucionales.

Además, la Constitución mexicana regula, con un grado de detalle inhabitual en otras leyes fundamentales, las actividades, y configuración tanto del IFE (artículo 41), como del TEPJF (artículo 99). Dichas normas abordan multitud de temas que, al parecer, no han querido dejarse en manos del legislador ordinario.

La explicación de este "furor constitucional" respecto al control de los procesos electorales es, desde luego, la existencia de una reacción clara contra las situaciones de falseamiento del sufragio que eran tradicionales en la sociedad mexicana. Eso, hasta el punto de que, a partir de las reformas que introdujeron esta nueva manera de hacer las cosas, se ha utilizado el término "transición democrática," ${ }^{26}$ como si lo anterior hubiera sido un régimen autoritario.

De "dictadura perfecta" habló en su momento en televisión (agosto de 1990, en un encuentro de intelectuales organizado por la prestigiosa revista mexicana "Vuelta") el futuro premio Nobel de Literatura, Mario Vargas Llosa, delante nada menos que de Octavio $\mathrm{Paz}_{1}{ }^{27}$ dictadura basada en mejores o peores técnicas de despiste, y ocultación de la realidad. En ella el partido dominante (el PRI, como se sabe) fundaba parte de su control de las realidades sociales, y del Estado, en un fraude electoral de cierta importancia.

El problema, sin embargo, es que en todos los procesos de democratización en los que se introduce el sufragio universal, al que lógicamente no se puede renunciar, aparecen los consiguientes desequilibrios. Sobre todo cuando nos encontramos en un contexto de pobreza, subdesarrollo, y retraso educativo, en el que, a veces, incluso persisten problemas de analfabetismo. Es obvio que estos hacen que el uso de

Civitas-Thomson, Cizur Menor, 2013, p. 19.

26

Aunque algunos prefieran hablar de “democratización”, por ejemplo, Robledo Rincón, Eduardo, $L a$ democratización en México, ¿cambio o evolución del régimen?, Tesis doctoral inédita defendida en la Facultad de Derecho de la Universidad Complutense de Madrid, 2011-2012, p. 71.

27

Véase, Vargas Llosa, Mario, “La dictadura perfecta”, sección “Tribuna”, El País, 1 de junio de 1992, para una explicación por escrito, y a posteriori, del responsable de la expresión; Krauze, Enrique, “La dictadura perfecta", Letras Libres, 12 de noviembre de 2012, en donde se recuerdan las circunstancias del incidente. 
Este obra forma parte del acervo de la Biblioteca Jurídica Virtual del Instituto de Investigaciones Jurídicas de la UNAM www.juridicas.unam.mx

determinados medios de comunicación, singularmente los escritos, tenga una influencia pobre sobre sectores significativos del electorado.

Surgen, por tanto, obstáculos para que se pueda hablar, como hace el texto constitucional mexicano, de "elecciones auténticas" (artículo 41), dado que los intentos de adoctrinar-informar a los votantes, en el desarrollo de campañas políticas, se enfrentan a serias dificultades, y las alternativas son medios de persuasión no siempre propios de un sistema democrático (compra de votos, o coacción pura y simple).

Estas situaciones, hoy propias aún de algunas zonas de México, son las habituales en los países que han combinado el intento de hacer participar a todos los ciudadanos, sin excepción, en los procesos electorales, con una conciencia cívica escasamente desarrollada. En España sabemos mucho de esto, hasta el punto de que entre nosotros, se ha hablado de "una historia de falseamiento". ${ }^{28}$

Y esa historia ha sido decisiva para la regulación, hoy vigente, de la administración electoral, ${ }^{29}$ de manera que el modelo español "se caracteriza por ser un modelo institucional independiente... (en el que)... los órganos electorales no dependen jerárquica ni funcionalmente del poder ejecutivo... (y)... los principios que articulan sus actuaciones denotan un compromiso explícito con la objetividad y neutralidad política". ${ }^{30}$

Sin profundizar en exceso su regulación, sí merece la pena repasar los caracteres que a dichos órganos atribuye Enrique Arnaldo; a saber, que se trata de una administración "independiente... exenta de cualquier tutela", "netamente judicializada en su composición", "especializada a la que se encomienda el ejercicio de la máxima autoridad

28

Rallo Lombarte, Artemi, Garantías electorales y Constitución, Madrid, CEPC, 1997, p. 33; un trabajo detallado sobre la historia de la administración electoral en España, Martínez Ruano, Pedro, Antecedentes históricos de la administración electoral, Almería, Universidad de Almería, 2008; Pastor Albaladejo, Gema, Calidad de la democracia y administración electoral, Madrid, Congreso de los Diputados, 2011, pp. 135-286; García Soriano, María Vicenta, Jueces y magistrados..., cit., pp. 31-57.

29

García Soriano, María Vicenta, Jueces y magistrados..., cit., pp. 67-145; Pascua Mateo, Fabio, La administración electoral, Madrid, INAP, 2007; Rallo Lombarte, Artemi, op.cit., pp. 193 y ss.; Arnaldo Alcubilla, Enrique, "La administración electoral como administración de garantía de las elecciones libres", en Pascua Mateo, Fabio (dir.), Estado democrático y elecciones libres: cuestiones fundamentales de derecho electoral, Asamblea de Madrid, Thomson-Civitas, 2010; Santolaya Machetti, Pablo, Procedimiento y..., cit., pp. 17 y ss.

${ }^{30}$ Pastor Albaladejo, Gema, op.cit., p. 575. 
Este obra forma parte del acervo de la Biblioteca Jurídica Virtual del Instituto de Investigaciones Jurídicas de la UNAM www.juridicas.unam.mx

en materia electoral", "integrada por un complejo de órganos... juntas y mesas electorales", "no permanente, con excepción de la Junta Electoral Central y de las Juntas Electorales de Comunidad Autónoma", y "jerarquizada". ${ }^{31}$

También el rechazo a prácticas corruptas y de abuso de mayorías, muy consolidadas, ${ }^{32}$ ha conducido, en la experiencia reciente (a partir de 1977), a una regulación compleja y estricta, con la que se procede a controlar que las decisiones de esa administración electoral están ajustadas a derecho.

Desde la revisión administrativa de las mismas hasta los recursos ante el Tribunal Constitucional, ${ }^{33}$ pasando por los que se sustancian ante los tribunales ordinarios, ${ }^{34}$ también en procesos especializados que se denominan de "contencioso-electoral" ${ }^{35}$ todo está orientado a que no quede ningún posible vacío que dé facilidades para que se produzcan abusos. Por encima de todo este sistema nacional de control por los tribunales está, desde luego, y dados los compromisos internacionales adquiridos, el de protección europea de derechos humanos, derivado de las competencias del Tribunal de

${ }^{31}$ Arnaldo Alcubilla, Enrique, op. cit, pp. 369-375.

32

El clásico, sobre el asunto, en el sistema político de la Restauración (1875-1923) es Costa Martínez, Joaquín, Oligarquía y caciquismo como la forma actual de gobierno en España: urgencia y modo de cambiarla, Madrid, Biblioteca Nueva, 1998; la reflexión, mucho más tarde, de un historiador, Varela Ortega, José, Los amigos políticos. Partidos, elecciones y caciquismo en la Restauración (1875-1900), Madrid, Alianza Universidad, 1977.

${ }^{33}$ El llamado amparo electoral, véase, Rallo Lombarte, Artemi, op. cit., pp. 103 y ss.; Santolaya Machetti, Pablo, Procedimiento y..., cit., pp. 174 y ss.

${ }^{34}$ Rallo Lombarte, Artemi, op. cit., pp. 133 y ss.

35

Sobre estos últimos, Santolaya Machetti, Pablo, Procedimiento y..., cit., pp.167 y ss.; un repaso a todos estos medios de control jurídico de las elecciones, García Soriano, María Vicenta, Jueces y magistrados..., cit., pp.149-355; Pascua Mateo, Fabio, El control de las elecciones, Civitas-Thomson, Madrid, 2009; Pascua Mateo, Fabio, "La unidades de la administración gubernativa de apoyo técnico al proceso electoral", en Pascua Mateo, Fabio (dir.), Estado democrático y elecciones libres: cuestiones fundamentales de derecho electoral, Asamblea de Madrid, Thomson-Civitas, 2010; Entrena Cuesta, Ramón, “Justicia electoral”, en Pascua Mateo, Fabio (dir.), Estado democrático..., cit, González Rivas, Juan José, “Análisis de los recursos de amparo electorales a la vista de la jurisprudencia constitucional" en Pascua Mateo, Fabio (dir.), Estado democrático..., cit; 
Este obra forma parte del acervo de la Biblioteca Jurídica Virtual del Instituto de Investigaciones Jurídicas de la UNAM www.juridicas.unam.mx

Estrasburgo. ${ }^{36}$

Especialmente llamativo es el hecho de que cuando se aborda la regulación del control de las elecciones, $y$, en concreto, el de las actas, tras la recuperación de la democracia todos los partidos significativos aceptan que se profundice en el modelo de “judicialización", que se había intentado tímidamente, mucho tiempo atrás en la llamada "Ley Maura" (por su principal inspirador, Antonio Maura, político conservador regeneracionista) de 1907. El Real Decreto Ley 20/1977 del 18 de marzo que reguló las normas electorales, lo adoptó sin reservas, rompiendo así con la solución tradicional, en la que la "limpieza" o "suciedad" de las actas que presentaban ante las Cortes los parlamentarios electos, era enjuiciada por las mismas Cámaras.

La crítica demoledora a estas reglas históricas, basándose en la paciente revisión tanto de la normativa como de la práctica, ha determinado que el Congreso de los Diputados, y el Senado, en España, no puedan ejercer ningún tipo de control sobre los problemas jurídicos que puedan presentarse. $Y$ eso a partir de las primeras elecciones celebradas tras el retorno del sistema democrático (junio de 1977). La Constitución española ha adoptado esta solución en el lacónico artículo 70.2 que dice que "la validez de las actas y credenciales de los miembros de ambas Cámaras estará sometida a control judicial, en los términos que establezca la ley electoral".

Quien analizó, en su momento, la realidad histórica española previa a este golpe de timón, habla por ejemplo de "verificación de poderes como institución al servicio de la mayoría parlamentaria", o de "dominio de la comisión de actas por la mayoría parlamentaria". ${ }^{37}$

La teoría clásica negaba la posibilidad de que un Parlamento "soberano" admitiera "un control externo de su propia composición". También que este control se ejercitara por "órganos provenientes del antiguo régimen, hostiles a la revolución", como los jueces de los primeros tiempos del constitucionalismo. El cambio se produjo cuando prevalecieron "las exigencias del Estado de Derecho y la aceptación de la naturaleza materialmente jurisdiccional de la función de controlar la legalidad de los procesos electorales". ${ }^{38}$

\footnotetext{
${ }^{36}$ García Soriano, María Vicenta, Jueces y magistrados..., cit., pp. 357-368.

${ }^{37}$ Fernández-Miranda Campoamor, Carmen, La verificación de poderes, Madrid, UNED, 1987, pp. 66 y 110.

${ }^{38}$ Ibidem, p. 13
} 
Este obra forma parte del acervo de la Biblioteca Jurídica Virtual del Instituto de Investigaciones Jurídicas de la UNAM www.juridicas.unam.mx

Es de señalar, sin embargo, que en algunos ordenamientos europeos como el italiano, se mantienen las soluciones superadas en España, puesto que quienes juzgan "sobre la regularidad de las elecciones, y también sobre el cumplimiento de los requisitos para la admisión al cargo electivo son los parlamentarios, esto es los colegas del elegido sujeto a control... sin que se reconozca... la posibilidad de recurrir contra la decisión ante un juez". ${ }^{39}$ En el país trasalpino todo el procedimiento se desarrolla ante los órganos legislativos, primero la Junta para las elecciones de la Cámara, y la Junta para las elecciones y la inmunidad parlamentaria del Senado, y luego los respectivos plenos.

La ley fundamental de Bonn dispone, por su parte, que "el control de las elecciones compete al Bundestag (Cámara de representación popular que lo delega en una de sus comisiones)", pero, contra dicha decisión "se admite el recurso de queja ante la Corte Constitucional Federal" (artículos $41,10$. y 20.). ${ }^{40}$

Se respeta así, en la que puede considerarse como la Constitución alemana, la solución tradicional de control por parte del Parlamento, si bien, en este caso, queda abierta la posibilidad de que el órgano de justicia constitucional revise las decisiones de aquél; debe recordarse que lo hace en exclusiva, porque ese problema de la validez de la elección "no puede ser objeto de otro procedimiento" judicial, como nos aclara Maunz. ${ }^{41}$

Una regulación similar a la española también rompiendo con las aproximaciones de siempre, es la francesa. En su norma fundamental (artículo 59); ${ }^{42}$ se atribuye en exclusiva, porque el resto de las jurisdicciones no participan en el control, la decisión sobre "la regularidad de la elección de diputados y senadores", al Consejo Constitucional.

Dicha regla ha sido considerada por la doctrina como "un progreso incontestable del

\footnotetext{
${ }^{39}$ Frosini, Tommaso Edoardo, Le votazioni, Laterza, Roma-Bari, 2002, p.35.

${ }^{40}$ Maunz-Zippelius, 1991, p. 375

41

Maunz, Theodor, “Comentario al artículo 41", en Maunz-Dürig-Herzog-Scholz, Grundgesetz Kommentar, München, C. H. Beck, 1960, p. 6. Un comentario más reciente a ese artículo constitucional, Pieroth, Bodo,“Comentario al artículo 41", en Jarass/Pieroth, Grungesetz für die Bundesrepublik Deutschland. Kommentar, 2da. ed., München, C. H. Beck, 1992, pp. 502 y ss.
}

42

Un breve comentario, Formery, Simon-Louis, La Constitution Commentée, 12a. ed., París, Hachette, 20082009, p. 124 
Este obra forma parte del acervo de la Biblioteca Jurídica Virtual del Instituto de Investigaciones Jurídicas de la UNAM www.juridicas.unam.mx

Estado de derecho". ${ }^{43}$ Se trata de una de las competencias más importantes del órgano francés de control de constitucionalidad, ${ }^{44}$ y forma parte del conocido diseño "gaullista" de las instituciones, que tiene como una de sus bases la limitación de la "soberanía parlamentaria", así como la revisión crítica de las prerrogativas de las Cámaras, por los abusos que se habían producido. Por ejemplo, la invalidación de las actas de los diputados de grupos políticos antisistema (los Ilamados "poujadistas"), en las elecciones anteriores a la crisis que llevó al cambio constitucional de $1958 .{ }^{45}$

No hay que perder de vista, por otra parte, y esto es relevante para un presidencialismo como el mexicano, que el "Conseil" tiene atribuida la competencia de resolver también los recursos que puedan plantearse en los procesos de elección del presidente de la República y en los de los referendos (artículos 58 y 60, de la Constitución francesa de 1958).

En el primer caso, y en un régimen tildado de "semipresidencialista", el control de la campaña electoral lo realiza con la colaboración de instituciones independientes como la CNC ("Comision nationale de contrôle de la campagne électoral à l'election du Président de la République"), el CSA ("Conseil supérieur de l'audovisuel", y la CCFP ("Commission nationale des comptes de campagne et des financement politiques).

Esto no deja de plantear problemas de convivencia, como ha explicado la doctrina, pero el hecho relevante es que a pesar de compartir poderes con esos organismos, Francia sigue siendo un ejemplo de cómo, contra lo propio de su historia, parece firmemente establecido un control jurisdiccional de los principales procesos electorales. $^{46}$

Es significativo, por otra parte, que en la cuna del parlamentarismo (Reino Unido, como se sabe, Westminster como "mother of Parliaments" "madre de Parlamentos"),

43

Favoreu, Louis et al., Droit constitutionnel, 6a. ed., París, Dalloz, 2003, p.282.

44

Sobre los detalles de la misma, véase, Jan, Pascal, Le procès constitutionnel, París, L. G. D. J, 2010, pp. 43 y SS.

${ }^{45}$ A ese caso hace una referencia muy breve, en la que dice que "no ha contribuido a reducir el antiparlamentarismo", Formery, Simon-Louis, op. cit., p. 124

46

Drago, Guillaume, Contentieux constitutionnel français, 3ra. ed., París, PUF, 2011, pp. 206 y ss. 
Este obra forma parte del acervo de la Biblioteca Jurídica Virtual del Instituto de Investigaciones Jurídicas de la UNAM www.juridicas.unam.mx

desde una ley aprobada en 1868 (Election Petitions and Corrupt Practices Act), se transfirió la jurisdicción sobre estos problemas, de control electoral de la Cámara de los Comunes a la Judicatura.

Sucesivas reformas como (Parliamentary Elections and Corrupt Practices Act de 1883; Corrupt and Illegal Practices Prevention Act 1883; Representation of the People Act 1983, que es el derecho vigente) fueron puliendo el sistema pero sin abandonar el control judicial, atribuido a una "Election Court" formada por dos jueces de la "High Court", que van rotando sin que participe en el proceso, contra lo que sucede en muchos supuestos en Gran Bretaña, ningún tipo de jurado. Sus fallos son apelables, si el mismo tribunal da su permiso y sólo respecto a sus fundamentos jurídicos, ante la "Court of Appeal", cuya decisión es ya definitiva.

Ello debe matizarse en el sentido de que, desde el caso $R$ (Woolas) vs. Parliamentary Election Court (2010), es posible impugnar las resoluciones (de lo que, al fin y al cabo, es un tribunal electoral especializado que no se considera un órgano del Poder Judicial), ante la jurisdicción ordinaria, dentro de lo que los británicos llaman las competencias de “judicial review" (revisión por los jueces) de esta última. ${ }^{47}$

Hay que decir que estos organismos europeos, de los que hemos hablado hasta ahora, no se han planteado muchas veces (o al menos, no he sido capaz de encontrar las referencias correspondientes) problemas de libertad de expresión en campaña electoral, quizás porque los mismos se conectan con la protección general de este derecho, confiada a los órganos jurisdiccionales ordinarios, civiles o penales, y en último término a los que tienen a su cargo los procedimientos de protección específica de los derechos fundamentales, tanto en las diferentes naciones (tribunales constitucionales o supremos), como en todo el continente (Tribunal de Justicia de las Comunidades Europeas y Tribunal Europeo de Derechos Humanos).

Una excepción a la regla, precisamente en Inglaterra, es el caso $R$ (on the application of Pro Life Alliance) v. BBC, que se dilucidó en 2004, con tesis contradictorias ante el Tribunal de Apelación y la Cámara de los Lores (entonces la más alta instancia judicial en el Reino Unido, sustituida ahora por un Tribunal Supremo) que convalidó un tipo curioso

47 Los detalles de la historia de este problema y su actual regulación, Morris, Caroline, Parliamentary Elections, Representation and the Law, Hart, Oxford and Portland, 2012, pp. 68 y ss. 
Este obra forma parte del acervo de la Biblioteca Jurídica Virtual del Instituto de Investigaciones Jurídicas de la UNAM www.juridicas.unam.mx

de censura ejercida por la BBC. ${ }^{48}$

Es preciso recordar que tanto en la Carta Europea de Derechos Humanos -artículo 11- como en el Convenio Europeo de Derechos Humanos - artículo 10- reconocen la libertad de expresión, y que la jurisprudencia del Tribunal de Estrasburgo, a la que ya hemos hecho alguna referencia es particularmente abundante y existe algún fallo relacionado con los procesos electorales. ${ }^{49}$

En el caso del de Luxemburgo no deja de haber los correspondientes. ${ }^{50}$

Volviendo al caso español, parece necesario revisar cuáles son los órganos que tienen atribuido el control de la libertad de expresión en las campañas, que es el tema que nos ocupa. De acuerdo con lo establecido en la LOREG, y como explican los autores ya citados, ${ }^{51}$ pueden tomar decisiones en sus respectivos ámbitos, las Mesas Electorales, las Juntas Electorales de Zona, las Provinciales, las de Comunidad Autónoma, y, por fin, la Electoral Central.

En todos estas instituciones interviene para decidir su composición, el sorteo (entre todos los ciudadanos en el caso de las Mesas, y entre magistrados en una parte de las Juntas, que se integran, además, por juristas y profesores designados por las fuerzas políticas) en un intento de introducir factores de neutralidad en unos órganos que han sido considerados como "administraciones independientes", ${ }^{52}$ a pesar de que otros

${ }^{48}$ Barendt, Eric, op. cit., pp. 46 y 47; en castellano, Torres Muro, Ignacio, “La libertad de expresión..., cit., pp. 136 y 137.

49

García Roca, Javier, op. cit., y Bustos Gisbert, Rafael, “Los derechos de libre comunicación en una sociedad democrática (artículo 10 CEDH)", en García Roca, J. y Santolaya, P. (coords.), La Europa de los derechos: el Convenio Europeo de Derechos Humanos, 2da. ed., Madrid, Centro de Estudios Políticos y Constitucionales, 2009.

50

Pronunciamientos, cabe remitir a la síntesis que se contiene en Jarass, Hans D., Charta der Grundrechte der Europäische Union. Kommentar, 2da. ed., München, Beck, 2013, pp. 121-139; en inglés, pero algo anticuado, Apt, Benjamín L., “On the Right to Freedom of Expression in the European Union”; 4 Columbia Journal of European Law69, 1998; debo este dato a mi colega, el profesor de Derecho de la Unión Europea de la Complutense, Pablo González.

${ }^{51}$ Rallo Lombarte, Artemi, op. cit., Pascua Mateo, Fabio, La administración..., cit., Santolaya Machetti, Pablo, Procedimiento y..., cit.

52 Ibidem, pp. 220 y ss.; Santolaya Machetti, Pablo, Procedimiento y..., cit, p. 32. 
Este obra forma parte del acervo de la Biblioteca Jurídica Virtual del Instituto de Investigaciones Jurídicas de la UNAM www.juridicas.unam.mx

autores se muestran críticos con dicho encuadramiento, y prefieren hablar de “organización administrativa del órgano constitucional cuerpo electoral". ${ }^{53}$

Junto a las mismas existen una serie de órganos auxiliares, integrados en la administración gubernativa, como la Oficina del Censo electoral, la Comisión de Radio y Televisión, y otras unidades gubernativas. El segundo, sobre todo, tiene una cierta influencia en la tarea de repartir equitativamente los espacios disponibles en los medios públicos y privados, para los mensajes de campaña electoral. Sin embargo, no en “materia de supervisión de la información política que puedan elaborar y difundir los medios de comunicación de titularidad pública en campaña, puesto que son las Juntas correspondientes, y en especial la Central, las que ostentan todas las facultades". ${ }^{54} \mathrm{Su}$ tarea de proponer acuerdos no deja, en todo caso, de ser necesaria para el sistema.

Dicha Comisión (artículo 65 de la LOREG) ${ }^{55}$ está claramente subordinada a la Junta Electoral correspondiente (Central, de la Comunidad Autónoma, o Provincial), que es la que decide sobre la distribución de espacios, a propuesta de aquélla (artículos 65.1, y 20. de la LOREG).

Es nombrada por la Junta de su ámbito territorial y se compone de un representante de cada uno de los partidos, federaciones, o coaliciones, que participan en las elecciones, teniendo ya representación en el Congreso de los Diputados. En la misma se vota por el sistema de voto ponderado, dependiendo de la fuerza en la Cámara Baja de los entes representados por cada uno de los miembros, aunque la doctrina ha apuntado que "por lo general... los acuerdos se toman por consenso" ${ }^{56}$ su presidente lo elige la Junta Electoral.

\section{ALGUNAS RESPUESTAS DE LA PRÁCTICA ESPAÑOLA A LOS PROBLEMAS DE LIBERTAD DE EXPRESIÓN EN LAS CAMPAÑAS ELECTORALES}

Después de estas divagaciones sobre los métodos de control de los procesos electorales, centrado en el de la libertad de expresión en las campañas, conviene que pasemos a las

\footnotetext{
${ }^{53}$ Pascua Mateo, Fabio, La administración..., cit., pp. 46-53, para la exposición de la teoría dominante, y 59-62, para la defensa de su original tesis.

${ }^{54}$ Pascua Mateo, Fabio, La administración..., cit., p. 119.

${ }^{55}$ Ibidem, pp. 116 y ss.

${ }^{56}$ Ibidem, p. 117.
} 
Este obra forma parte del acervo de la Biblioteca Jurídica Virtual del Instituto de Investigaciones Jurídicas de la UNAM www.juridicas.unam.mx

soluciones que se han dado a estos asuntos en el ordenamiento español, que son las que conocemos mejor, por si ellas pueden resultar útiles para la posterior revisión de las mexicanas.

Del estudio de la normativa electoral (LOREG), y de las interpretaciones de la misma por parte de los Acuerdos de la Junta Electoral Central (en adelante AJEC), pueden deducirse, en apretada síntesis, siguiendo al profesor Pablo Santolaya, y a la bibliografía, ${ }^{57}$ una serie de pautas que pasamos a comentar.

Sin embargo, debemos primero volver sobre la idea de que el tratamiento jurídico de estos problemas se realiza teniendo en cuenta dos tipos ideales: por una parte, el norteamericano del "libre mercado de las ideas", basado en "la garantía de una posición de igualdad... (entre los candidatos)... respecto a la compra de espacios publicitarios"; y por otra, el de la llamada "opinión pública libre" habitual en Europa, y propio de España que pretende "garantizar un equilibrio de influencias entre las distintas corrientes de opinión". ${ }^{58}$

La primera pauta es la referente a las llamadas campañas "institucionales", ${ }^{59}$ que se han restringido mucho en España, desde el momento en que, por un lado, solamente pueden Ilevarlas a cabo "los poderes públicos que en virtud de su competencia legal hayan convocado el proceso electoral", y por otro, deberán estar destinadas exclusivamente a "informar a los ciudadanos sobre la fecha de la votación, el procedimiento para votar y los requisitos, y trámites del voto por correo, sin influir, en ningún caso, en la orientación del voto de los electores" (artículo 50.1, LOREG; ver también AAJEC del 13 de mayo de 1999, 19 y 25 de enero de 2005, y 24 de mayo de 2006).

Nos hallamos, por tanto, ante una limitación radical de los posibles sujetos (sólo están facultados para hacer este tipo de campaña, repetimos, los que convocan las elecciones),

57

Santolaya Machetti, Pablo, Procedimiento y..., cit, pp. 125 y ss.; Recoder Vallina, Tatiana, “Las campañas en periodo electoral: la campaña electoral y la campaña institucional", en Pascua Mateo, Fabio (dir.), Estado democrático y elecciones libres: cuestiones fundamentales de derecho electoral, Asamblea de Madrid, Thomson-Civitas, 2010, pp. 507-542.

58

Sánchez Muñoz, Oscar, La igualdad de oportunidades en las competiciones electorales, Madrid, CEPC, 2007, pp. 81 y 82.

${ }^{59}$ Para un repaso a la normativa y a la bibliografía, véase, Recoder Vallina, Tatiana, op. cit., pp. 535-542. 
Este obra forma parte del acervo de la Biblioteca Jurídica Virtual del Instituto de Investigaciones Jurídicas de la UNAM www.juridicas.unam.mx

de manera que se excluye de la participación en la misma a quienes muchas veces tienen tanto o mayor interés en dichos procesos, siendo como son entes públicos. Por ejemplo: los ayuntamientos en elecciones locales o el Parlamento europeo en elecciones de ese alcance, que se ven imposibilitados de realizar una campaña institucional, porque en ambos casos, quien convoca es el gobierno español.

Por otra parte, en cuanto se excluye uno de los objetivos principales de toda campaña institucional (incentivar el ejercicio del derecho al voto) parece que las actividades permitidas deben limitarse a recordar al elector los aspectos técnicos del proceso. Las dos soluciones aparecen consolidadas aunque no exentas de críticas. ${ }^{60}$

Conectado con el problema anterior está el de las campañas "informativas" sobre la gestión y las inauguraciones, que como se sabe pueden constituirse en intentos de apoyar las posibilidades electorales de quienes se encuentran en el poder y por tanto, tienen una mayor visibilidad en ese tipo de actos, y en la propaganda de "éxitos" en las tareas de gobierno.

La LOREG es particularmente radical (artículo 50, apartados 2, y 3) al disponer que "desde la convocatoria de elecciones y hasta la celebración de las mismas queda prohibido cualquier acto organizado o financiado, directa o indirectamente, por los poderes públicos que contenga alusiones a las realizaciones o a los logros obtenidos, o que utilice imágenes o expresiones coincidentes o similares a las utilizadas en sus propias campañas por alguna de las entidades políticas concurrentes a las elecciones"; y que "asimismo, durante el mismo periodo queda prohibido realizar cualquier acto de inauguración de obras o servicios públicos o proyectos de éstos, cualquiera que sea la denominación utilizada, sin perjuicio de que dichas obras o servicios puedan entrar en funcionamiento en ese periodo".

La doctrina de la Junta Electoral Central que debe aplicar estas normas a los casos concretos, se ha encontrado con serias dificultades para hacerlo, hasta el punto de que ha sido calificada de "un tanto errática e impredecible". ${ }^{61}$ Este autor es muy crítico con estas soluciones que considera no proporcionadas "a la finalidad que se pretende", además de no conseguir, tampoco, que desaparezca "significativamente la conflictividad

\footnotetext{
${ }^{60}$ El debate y las referencias bibliográficas pertinentes se resumen en Santolaya Machetti, Pablo, Procedimiento y..., cit, pp. 126 y ss.

${ }^{61}$ Ibidem, p. 131.
} 
Este obra forma parte del acervo de la Biblioteca Jurídica Virtual del Instituto de Investigaciones Jurídicas de la UNAM www.juridicas.unam.mx

jurídica". ${ }^{62}$

Respecto a los sujetos de la campaña ${ }^{63}$ nos encontramos con la necesidad de encontrar el equilibrio entre la regla (prevista en los artículos 50.4 y 5o., de la LOREG) de que sólo pueden "realizar campaña electoral a partir de la fecha de la convocatoria de las elecciones" los que las hayan convocado (campaña institucional), y los "candidatos, partidos, federaciones, coaliciones o agrupaciones en orden a la captación de sufragios"; y la de que, como está de más decir, todo ello debe respetar "lo establecido en el artículo 20 de la Constitución (que reconoce, aclaramos, las libertades de expresión e información)". Tampoco aquí ha sido fácil la aplicación práctica de esta normativa aun cuando existían sentencias del TEDH que orientaban por el buen camino. ${ }^{64}$

Parece que la Junta Electoral Central va encontrando poco a poco (por ejemplo, AJEC del 2 de febrero de 2012), el equilibrio entre las intromisiones inaceptables en el proceso electoral de entes ajenos al mismo, y el respeto a la libertad de expresión reconocida a todos los ciudadanos por normas igualmente importantes o incluso de rango superior que las electorales, como es en el caso de España, el ya citado artículo 20 de la Constitución.

Teniendo en cuenta este último dato, la solución correcta a los casos concretos debe partir, a mi juicio, de la base de que estamos, como hemos repetido ya hasta la saciedad, ante un derecho fundamental imprescindible para el buen funcionamiento de las sociedades democráticas, de modo que solamente debe ser limitado cuando los valores e intereses en presencia sean igualmente importantes.

Y su sacrificio en el altar de la igualdad de oportunidades, o equidad, en las campañas, debe hacerse exclusivamente si como dice el artículo 20, CE, en su apartado 4, nos encontramos ante la exigencia de respetar otros derechos fundamentales, "los preceptos de las leyes que los desarrollen... el derecho al honor, a la intimidad, a la propia imagen y a la protección de la juventud y de la infancia". O, por supuesto, los valores superiores del ordenamiento ("la libertad, la justicia, la igualdad y el pluralismo político", artículo 1.1, CE).

\footnotetext{
${ }^{62}$ Ibidem, p. 134.

${ }^{63}$ Ibidem, pp. 134 y 135; Recoder Vallina, Tatiana, op. cit., pp. 510-514.

${ }^{64}$ Singularmente, Bowman vs. Reino Unido, del 19 de febrero de 1998.
} 
Este obra forma parte del acervo de la Biblioteca Jurídica Virtual del Instituto de Investigaciones Jurídicas de la UNAM www.juridicas.unam.mx

En cuanto a los límites a la libertad de expresión en la precampaña y en la jornada previa a las votaciones así como el día en que se producen las mismas, hay que tener en cuenta, respecto a los dos últimos problemas, que el artículo 53, LOREG dispone que "no puede difundirse propaganda electoral ni realizarse acto alguno de campaña electoral una vez que esta haya legalmente terminado"; esto es "a las cero horas del día inmediatamente anterior a la votación"(véase la interpretación de esta norma por la JEC, en la circular del 26 de mayo de 1991-referencias en medios a actos de campaña del día anterior-; AJEC del 26 de mayo de 1991, y 10 de mayo de 1995 -campaña institucional-; AJEC del 1 de diciembre de 2011 llamada de un cargo público a votar a su partido al salir del colegio electoral).

De nuevo nos encontramos ante la necesidad de compatibilizar estas prohibiciones con la libertad de expresión, como, también lo recuerda el citado artículo 53 de la LOREG, en el último inciso de su primer párrafo. Allí se refiere a las excepciones derivadas del “ejercicio de sus funciones constitucionalmente reconocidas, y en particular, en el artículo 20 de la Constitución".

Y lo que, desde luego, es totalmente desmesurado es la utilización del derecho penal, configurando como delito (artículo 144.1, LOREG) castigado con pena de prisión de tres meses a un año, o la de multa de seis a veinticuatro meses, el hecho de "realizar actos de propaganda una vez finalizado el plazo de la campaña electoral".

Más parece que el respeto a la "jornada de reflexión" ${ }^{165}$ no es tan importante como para ser protegido a través de sanciones penales, impropias para el control de conductas que no tienen tanta trascendencia como la que parece atribuírsele en la norma citada.

Si tenemos como norte el famoso principio de "intervención mínima" ${ }^{\prime 66}$ a la hora de perseguir con la "artillería pesada", unos hechos que no suponen una vulneración que lesione los fundamentos del Estado de derecho, queda claro que criminalizar los mismos

\footnotetext{
${ }^{65}$ Recoder Vallina, Tatiana, op. cit., pp. 516 y 517.

66

En la jurisprudencia véase, sentencia del Tribunal Supremo español —Sala Segunda— núm. 670, del 21 de junio de 2006: "la sanción penal no debe actuar cuando existe la posibilidad de utilizar otros medios o instrumentos jurídicos no penales para restablecer el orden jurídico", Muñoz Conde, Francisco y García Arán, Mercedes, Derecho penal. Parte general, 7a. ed., Valencia, Tirant lo Blanch, 2007, pp. 70 y ss; Mir Puig, Santiago, Derecho penal. Parte general, 7a ed., Barcelona, Reppertor, 2006, p. 127. En ambos casos hay ediciones posteriores).
} 
Este obra forma parte del acervo de la Biblioteca Jurídica Virtual del Instituto de Investigaciones Jurídicas de la UNAM www.juridicas.unam.mx

es un error.

Convendría seguir teniendo claro que "el Derecho penal sólo debe intervenir en los casos de ataques muy graves a los bienes jurídicos más importantes". ${ }^{67}$ No imaginamos qué conducta de expresar ideas y consignas, fuera de los límites temporales de la campaña electoral, puede ser un "ataque muy grave" a un "bien jurídico de los más importantes". No cabe sino recomendar mesura en el manejo de dicha norma penal.

La precampaña es regulada por el segundo párrafo del artículo 53, LOTC, en el que se prohíbe "desde la convocatoria de las elecciones hasta el inicio legal de la campaña... la realización de publicidad o propaganda electoral mediante carteles, soportes comerciales o inserciones en prensa, radio u otros medios digitales, no pudiendo justificarse dichas actuaciones por el ejercicio de las actividades ordinarias de los partidos".

Esta norma - producto de la reforma de 2011—, tiene el sentido, como apunta Santolaya, de "disminuir los gastos de campaña de los partidos políticos limitando el tipo de actividades que pueden realizarse sin recibir por ello subvenciones públicas". ${ }^{68}$

Respecto a la propaganda electoral en medios públicos y privados, ambos deberán respetar "el pluralismo político y social, así como la igualdad". Los primeros tendrán que garantizar, además, "la proporcionalidad y neutralidad informativa" por su "organización", y por los controles de su actividad "previstos en las leyes". Las decisiones de sus órganos administrativos son, por otra parte, "recurribles ante la Junta Electoral competente" (artículo 66.1, LOREG).

Los segundos "deberán respetar también los principios de proporcionalidad y neutralidad informativa en los debates y entrevistas electorales así como en la información relativa a la campaña electoral de acuerdo a las Instrucciones que... elabore la Junta Electoral competente" (artículos 66 y 20., LOREG; recuérdese que tras la reforma de la misma, contenida en la LO 2/2011, del 28 de enero).

Estos preceptos tan rígidos, han sido muy criticados por los profesionales, con argumentos que recogen algunos autores, al decir que “la información electoral deja de estar regulada por criterios relacionados con la libertad de información... es sometida a

\footnotetext{
${ }^{67}$ Muñoz Conde, Francisco y García Arán, Mercedes, op. cit., p. 70.

${ }^{68}$ Santolaya Machetti, Pablo, Procedimiento y..., cit, p. 137.
} 
Este obra forma parte del acervo de la Biblioteca Jurídica Virtual del Instituto de Investigaciones Jurídicas de la UNAM www.juridicas.unam.mx

un estrecho criterio de proporcionalidad de los resultados electorales... (y controlada por) la JEC" ${ }^{69}$ lo cual no parece demasiado operativo, dada la competencia de los miembros, de esta última, en materia de comunicación.

Si los cambios en la LOREG se "han limitado a consagrar la doctrina creada por la Junta Electoral Central ${ }^{m 70}$ creemos que ésta es errónea, y en exceso extremista, pues se basa en una desconfianza exagerada hacia los informadores, que lesiona su independencia y constituye una manera de entender la neutralidad, y el pluralismo, basada en un gusto por la exactitud matemática, que es inadecuado para tratar estos asuntos. El resultado es que no hay tratamiento informativo sino mera transmisión de lo que los actores electorales suministran, lo que supone entrar en el terreno del más burdo adoctrinamiento, inapropiado para una sociedad verdaderamente libre.

Los artículos 54 a 57 de la LOREG regulan, por su parte, la cesión de lugares por los ayuntamientos, para celebrar actos electorales o la colocación de propaganda. De nuevo, a través de las decisiones de la Junta Electoral de Zona, favoreciendo a los grupos ya consolidados (artículo 56.2, LOREG). Los espacios, en medios de comunicación públicos, se distribuyen de acuerdo con el principio de que no se pueden contratar en ellos espacios de publicidad electoral (artículo 60.1, LOREG), y el de que los contendientes tienen derecho a espacios gratuitos (artículo 60.2, LORG). Se vuelven a tener muy en cuenta los resultados obtenidos con anterioridad (artículos 61, 62, 63, y 64, LOREG), y el control del reparto corresponde a la Junta Electoral competente (artículo 65, LOREG). ${ }^{71}$

En cuanto a los medios privados la normativa es cuando menos, chocante. Por un lado se excluye de toda regulación a la prensa y radio, con la única excepción de las limitaciones del gasto electoral, y la prohibición de las discriminaciones en las tarifas entre candidaturas (artículo 58, LOREG); pero, por otro lado, se procede a poner bajo un control que pudiera ser lesivo de las libertades de información, expresión, ideológica, y de empresa, las actividades de las televisiones durante la campaña (artículo 66, LOREG, tras la reforma de la LO 2/2011, del 28 de enero, que ya hemos citado).

Esta "neutralidad ideológica" forzada y la proporcionalidad que criticábamos, en el

\footnotetext{
${ }^{69}$ Ibidem, p. 139.

${ }^{70}$ Ibidem, p. 139, la sintetiza en las pp. 137-139.

${ }^{71}$ Ibidem, pp. 140-144.
} 
Este obra forma parte del acervo de la Biblioteca Jurídica Virtual del Instituto de Investigaciones Jurídicas de la UNAM www.juridicas.unam.mx

caso de los medios públicos, y que aquí tiene aún menos sentido, olvidan que "en los medios privados el pluralismo debe ser el resultado del contraste entre las posiciones de cada uno de ellos en el libre juego del mercado de las ideas". Hay que permitir que, supuestos los controles de las juntas para evitar los desequilibrios claros, e inadmisibles, "cada medio mantenga su propia línea editorial". ${ }^{72}$ Las limitaciones no pueden llevar, se ha dicho, "al establecimiento de un régimen idéntico al de los medios públicos". ${ }^{73}$

Afortunadamente la Junta Electoral Central, en las correspondientes Instrucciones (4/2011, del 24 de marzo, por ejemplo) y en diversos acuerdos, ${ }^{74}$ ha matizado dicha normativa. La misma es, a todas luces, un caso de exceso en la regulación y ha provocado reacciones duras por parte de los informadores. ${ }^{75}$ Cabe, además, preguntarse con fundamento sobre su constitucionalidad, en cuanto incide de una manera especialmente intensa de las libertades básicas de comunicación reconocidas en el artículo 20, CE.

El buen tino de la Junta Electoral Central al desarrollar las previsiones legales, y al aplicarlas, moderando sus posibles consecuencias, es posiblemente la razón de que esas reglas no hayan sido cuestionadas, por ahora, ante los tribunales; $y$, finalmente, ante el garante de los derechos fundamentales (Tribunal Constitucional). Si esto se hiciera, asistiríamos a un interesante debate jurídico sobre los límites de las intervenciones, en materia de libertad de expresión en campañas, de las Juntas Electorales, que debemos reconocer que, en general, han hecho un buen trabajo en España, también en este terreno.

Sin embargo, algunos justifican esta normativa pues, según ellos "si se quiere garantizar el pluralismo informativo... es necesario que se impongan limitaciones al ejercicio de las libertades... (aún cuando)... una cosa es que los medios privados sean plurales por exigencia normativa, pero no pueden ser obligados a ser neutrales". ${ }^{76} \mathrm{Al}$ fin al cabo, un problema de difíciles equilibrios en el que no existen reglas generales y en el

\footnotetext{
${ }^{72}$ Ibidem, p. 146.

${ }^{73}$ Sánchez Muñoz, Oscar, op. cit., p. 258.

${ }^{74}$ Santolaya Machetti, Pablo, Procedimiento y..., cit, p. 147.

${ }^{75}$ Sánchez Muñoz, Oscar, op. cit., p. 262 y nota al pie 190.

${ }^{76}$ Recoder Vallina, Tatiana, op. cit., p. 525; el último inciso procede de Sánchez Muñoz, Oscar, op. cit., p. 258.
} 
Este obra forma parte del acervo de la Biblioteca Jurídica Virtual del Instituto de Investigaciones Jurídicas de la UNAM www.juridicas.unam.mx

que los órganos de la administración electoral deberán tener muy en cuenta las peculiares circunstancias de cada caso concreto.

Conviene que digamos algo en este apartado, sobre la realidad de la libertad de expresión en las campañas electorales en España, haciendo una breve referencia a la compleja problemática de los debates televisivos, ${ }^{77}$ protagonizados por los principales candidatos. El primer dato, al respecto, es la inexistencia de normas, sobre ellos, en la LOREG.

De hecho el único precepto existente es, curiosamente, un artículo de un Estatuto de Autonomía (el 105.2 de Andalucía) que dispone que la ley electoral de esa Comunidad Autónoma "regulará la obligación de los medios de comunicación de titularidad pública de organizar debates electorales entre la formaciones políticas con representación parlamentaria".

Dada la importancia que han adquirido recientemente (hasta el punto de ser considerados como un elemento básico en cualquier campaña electoral y constituir un innegable éxito de audiencia) tanto el Tribunal Supremo, a través de varias resoluciones, como la Junta Electoral Central con instrucciones y acuerdos, ${ }^{78}$ han venido a perfilar, poco a poco, un régimen jurídico de los mismos, que plantea la necesidad de que sirvan a su fin indiscutible, de que haya unas discusiones informadas sobre qué pretenden hacer en el futuro, en lo que se refiere a la manera de abordar los problemas sociales y políticos, de los principales protagonistas de los diferentes procesos electorales.

Sin embargo, de plantearse algunas dudas sobre la constitucionalidad de esta práctica, que Oscar Sánchez condensa en las siguientes: 1) se trata de "una medida que impone una obligación legal dirigida a los medios de comunicación públicos de organizar determinados tipos de emisiones", restringiendo la "libertad de programación... derivada de la libertad de información" (artículo 20.1, inciso d, CE); 2) el dilema de "si la organización obligatoria de debates es una medida que sólo se puede imponer a los medios públicos o también... extenderse a los privados, al menos a la televisión"; 3) "las fórmulas... concretas que se proponen, destinadas a favorecer el debate entre dos fuerzas políticas, dejando fuera al resto", y 4) "la obligación de las fuerzas políticas de

\footnotetext{
${ }^{77}$ Ibidem, pp. 262-269.

${ }^{78}$ Las referencias a todos estos materiales perfectamente actualizadas, Santolaya Machetti, Pablo, Procedimiento y..., cit, pp. 147-152.
} 
Este obra forma parte del acervo de la Biblioteca Jurídica Virtual del Instituto de Investigaciones Jurídicas de la UNAM www.juridicas.unam.mx

acudir a los debates y las posibles sanciones en caso de incumplimiento" (sentencia del Tribunal Supremo del 13 de febrero de 1996, que consideraba totalmente libre la asistencia). ${ }^{79}$

Lo cierto es que la práctica desde 2008, un año después de que se escribiera lo anterior, parece haber barrido todas las posibles objeciones, y este instrumento de la libertad de expresión electoral se ha consolidado cada vez más. ${ }^{80}$

Especial interés, en cuanto es un problema de conflicto entre la normativa electoral, y el ejercicio de un derecho constitucional, como el de manifestación (artículo 21, CE) uno de cuyos objetivos consiste en expresar opiniones e ideas- es la clara línea de la jurisprudencia del Tribunal Constitucional español, en el sentido de que (siempre teniendo presente el artículo 54.1 LORG, que atribuye a la Juntas Electorales, los poderes encomendados a la autoridad gubernativa en materia de "celebración de actos públicos de campaña electoral", que "se rige por lo dispuesto en la legislación reguladora del derecho de reunión") es rechazable la manera de abordar el problema de las tensiones entre las rígidas reglas sobre limitación temporal de la expresión política en las campañas, y la existencia, insistimos, de un derecho fundamental en juego, que a veces defendieron esas Juntas, al resolver que son inadmisibles todas las manifestaciones durante la campaña electoral. Más aún en la jornada de reflexión o en de la votación.

EI TC (principalmente en SSTC 170/2008, del 15 de diciembre; 37/2009, del 9 de febrero; 3/2009, del 9 de febrero; y 96/2010, del 9 de febrero) ha sostenido que el derecho de manifestación puede, por supuesto, ejercerse en periodos electorales, y que en los más delicados de las jornadas de reflexión y votación, sólo es admisible prohibir dichas formas de expresar ideas, y opiniones, en el caso de que tengan "contenido electoral".

La última de dichas sentencias recapitula las ideas principales de esa doctrina, afirmando que "el ejercicio del derecho de reunión... debe prevalecer salvo que resulte suficientemente acreditado... que la finalidad principal de la convocatoria es la captación de sufragios"( STC 96/2010, del 9 de febrero, FJ 3), y que "la mera posibilidad de que una reivindicación ...pueda incidir de una u otra forma en el electorado, se muestra como

\footnotetext{
${ }^{79}$ Sánchez Muñoz, Oscar, op. cit., pp. 267-269.

${ }^{80}$ Santolaya Machetti, Pablo, Procedimiento y..., cit., pp. 149 y ss.
} 
Este obra forma parte del acervo de la Biblioteca Jurídica Virtual del Instituto de Investigaciones Jurídicas de la UNAM www.juridicas.unam.mx

hipótesis insuficiente para limitar el derecho de reunión en periodo electoral (F) 4, de la misma sentencia).

El asunto no está ni mucho menos zanjado, como demuestran las circunstancias alrededor del AJEC del 19 de mayo de 2011, en el que la Junta Electoral Central dictó una resolución sobre desalojo de la Puerta del Sol (céntrica plaza de Madrid, ocupada por los llamados "indignados" del movimiento 15-M) que simplemente no fue obedecida por los que allí se concentraban, con la lógica tolerancia policial, ante la posibilidad de que se produjeran males mayores.

Del "planteamiento ante la Junta de problemas que no puede resolver", habla el profesor Santolaya, ${ }^{81}$ y no le falta razón en que el citado artículo 54.1, LOREG se ha interpretado de una manera que pone a las autoridades electorales ante unos dilemas de los que les resulta muy difícil ocuparse, en cuanto no son órganos apropiados para abordar asuntos de este tipo. Es verdad que el apartado 2 de dicho artículo 54, dice que "se mantienen, en todo caso, las atribuciones de la autoridad gubernativa respecto al orden público" pero el equilibrio entre ambas normas que dotan vagamente de competencias a unos y a otros, no parece fácil de alcanzar.

El supuesto al que acabamos de hacer referencia era, sin duda, uno de esos "casos difíciles que hacen mal derecho", ${ }^{82}$ y es de esperar que las incógnitas podrán despejarse poco a poco, en el futuro.

Dejamos para el final de este apartado, la referencia a un supuesto también límite, que puso a prueba las posibilidades de reacción de la normativa electoral cuando se intentó, abusando de la misma, introducir en la campaña (usando los espacios concedidos a una coalición electoral (Herri Batasuna) que agrupaba a sectores independentistas del País Vasco) mensajes intimidatorios de un grupo terrorista (ETA).

Los condenados por la jurisdicción ordinaria, por colaboración con banda armada,

${ }^{81}$ Ibidem, pp. 46 y ss., con una descripción de primera mano de las vicisitudes del caso.

82

El adagio en versión anglosajona sería "Hard cases make bad law"; véanse los votos de Rolfe en el pleito inglés, de 1842, Winterbottom vs. Wright, y de Holmes Jr, en el norteamericano, de 1904, Northern Securities Co vs. United Status, el jurista contemporáneo que le ha dado más juego teórico al mismo es, como se sabe, Dworkin, Ronald, Taking Rights seriously, 3ra. ed., Londres, Duckworth, 1981, capítulo 4, pp. 81 y ss. La versión española es, Dworkin, Ronald, Los derechos en serio, Barcelona, Ariel, 1984, capítulo 4, pp.146 y ss. 
Este obra forma parte del acervo de la Biblioteca Jurídica Virtual del Instituto de Investigaciones Jurídicas de la UNAM www.juridicas.unam.mx

recurrieron ante el Tribunal Constitucional alegando, entre otras cosas, que se había vulnerado su derecho a la libertad de expresión.

La respuesta del mismo en la STC 136/1999, del 20 de julio, fue, respecto a los límites de la libertad de expresión en campañas electorales, la siguiente: primero, que las medidas adoptadas para evitar la emisión del correspondiente video (secuestro, condena penal) perseguían fines legítimos (FJ 14); segundo (FJ 16) que el contenido del vídeo (reivindicaciones de innegociable contenido, expresa exhibición de armas, latente amenaza de violencia, recurso a la misma como forma de obtener sus reivindicaciones) excede claramente lo admisible, y finalmente (FJ 19), que el "comportamiento enjuiciado no respeta las reglas de la democracia y... no resulta amparado por la libertad de expresión".

De este modo, el Tribunal sentó que era posible usar las medidas habituales, (nunca anteriores a la publicación, dada la prohibición de la censura previa en el artículo 20.2, CE, y acordadas en virtud de resolución judicial, como exige el artículo 20.5, CE) para evitar la propagación de determinados materiales, y que no quedaban fuera de la posibilidad de la sanción penal los contenidos delictivos de los mismos. ${ }^{83}$

\section{NUEVOS DESARROLLOS EN LA JURISPRUDENCIA ELECTORAL MEXICANA}

El primer dato en este repaso a algunos aspectos de la jurisprudencia electoral mexicana que más le ha llamado la atención al autor de estas líneas, es "el excesivo uso de campañas negativas en contra del contendiente". ${ }^{84}$

Quizás esto tenga que ver con que las estrategias del insulto y la denigración sistemática del contrario, tienen más éxito en México que en otros países, en los que existen ciertas tradiciones y una cultura política que valoran negativamente dichas actitudes. Se trataría, por tanto, de un problema de base de muy difícil solución, a

83

Sobres esta sentencia véase, Bilbao Ubillos, Juan María, “La excarcelación tenía un precio: el Tribunal enmienda la plana al legislador (comentario de la STC 136/1999, en el caso de la Mesa Nacional de HB)", Revista Española de Derecho Constitucional, núm. 58, 2000; en especial, acerca del asunto de la libertad de expresión, pp. 286-292.

\footnotetext{
${ }^{84}$ Esquivel, Yessica, op. cit., p. 197; en lo que sigue nos apoyamos fundamentalmente en el trabajo de la autora que ha realizado una revisión de la jurisprudencia del TEPJF que, por muchas razones, no estaba a nuestro alcance.
} 
Este obra forma parte del acervo de la Biblioteca Jurídica Virtual del Instituto de Investigaciones Jurídicas de la UNAM www.juridicas.unam.mx

superar solamente cuando casi todos los integrantes del cuerpo electoral adquieran un nivel de discernimiento mucho mayor del que tienen en la actualidad.

Tampoco, en países más desarrollados, puede decirse que no exista el mismo, dada la vulgarización que sufre el discurso político en todo el planeta; pero también es verdad que, en muchos de ellos, el recurso al insulto está en desuso, no tanto porque los métodos de control y reacción frente al mismo sean plenamente eficaces sino principalmente porque muchas veces dicho instrumento se ha vuelto contra quienes han pretendido utilizarlo como arma electoral. Ya no es rentable o por lo menos no es tan rentable como antes. En consecuencia, los actores políticos evitan planteárselo a un electorado que puede rechazar dicho juego sucio, pasando a apoyar al insultado, o criticado con poca elegancia.

El caso es que algunos actores presentes en las campañas electorales mexicanas de los últimos años han hecho uso de estas técnicas, provocando la reacción de los denigrados, y, por tanto, la llamada a los órganos jurisdiccionales electorales a resolver sobre el tema. Y eso que la Constitución es clara, en el sentido de que "en la propaganda política o electoral que difundan los partidos deberán abstenerse de expresiones que... calumnien a las personas" (artículo 41, fracción III, inciso C, CPEUM). Sin embargo, uno repara fácilmente, en que dicha norma prohíbe las expresiones que "denigren a las instituciones y a los propios partidos", mientras que para las personas se utiliza el término penalmente más preciso, y de mayor gravedad ("calumnien"), de manera que la protección del honor de estas últimas parece tener mayores dificultades. Hay que decir, no obstante, que existen motivos para la esperanza, en el sentido del abandono paulatino de esa práctica, puesto que ya se ha podido escribir como conclusión a un análisis empírico, que “a partir de la reforma electoral 2007-2008 se percibe una disminución de las campañas negativas y de contraste. ${ }^{85}$

En todo caso, el protagonismo en la materia del TEPJF es indiscutible. Se ha enfrentado con una tarea nada fácil, en la que, lógicamente, ha ido construyendo su jurisprudencia caso a caso.

Recordemos que a un órgano de este tipo sería absurdo pedirle la coherencia de las

85

Juárez Gámiz, Julio y Brambila, José Antonio, “La publicidad política televisiva en el proceso electoral en México", Revista Mexicana de Derecho Electoral, núm. 4, 2013, p. 317. 
Este obra forma parte del acervo de la Biblioteca Jurídica Virtual del Instituto de Investigaciones Jurídicas de la UNAM www.juridicas.unam.mx

construcciones académicas, como a veces hacen algunos con evidente torpeza. Su labor no consiste en elaborar brillantes trabajos científicos, propios de los profesores, sino en ir, poco a poco, construyendo una doctrina coherente que oriente la actividad de los operadores en los procesos electorales, y por supuesto, de cumplida respuesta a los conflictos que se le planteen.

Aun cuando, como acabamos de señalar, los debates más frecuentes y profundos, giran alrededor del necesario respeto al rival, también se han puesto sobre la mesa otros problemas, en los que México no se diferencia tanto del resto de las democracias de masas. Por ejemplo, siguiendo a la doctrina de ese país, el hecho de que "es posible decir que en medios impresos sí se percibe claramente el pluralismo externo en la información que se divulga, contrario a lo que sucede en el caso de las televisoras en las que prevalece la uniformidad en la cobertura informativa y, por ello, no existe ningún tipo de pluralismo ni interno ni externo... como es precisamente la televisión... la que contribuye en mayor medida a informar y... construir la percepción del ciudadano sobre los candidatos, la ausencia de dicha pluralidad genera desigualdad en la contienda que resulta muy lesiva para la competencia electoral y, en general, para la democracia". ${ }^{86}$

También, como ocurre en todas partes, el nivel de información política presentada por los partidos... en su publicidad es escaso y... superficial... han aumentado los spots políticos de promoción que resaltan características insustanciales de los candidatos de manera unilateral... en la elección federal de 2012 hay una ausencia de producciones con contenido sustancial... la publicidad... televisiva favorece la personalización de la política. ${ }^{87}$

No menos importante es la llamada "tiranía del formato", desde el momento en que "al elevar las premisas del nuevo modelo de comunicación política a rango constitucional... (se ha producido una)...extrema rigidez y la dificultad de su cambio, acomodo y adaptación", por lo que parece necesario "reflexionar sobre la manera de introducir esquemas de flexibilización que... posibiliten un uso menos rígido de los

\footnotetext{
86 Cantú, Jesús et al., "Conexión entre medios de información y preferencias electorales", Revista Mexicana de Derecho Electoral, núm. 4, 2013, pp. 271 y 272.

${ }^{87}$ Juárez Gámiz, Julio y Brambila, José Antonio, op. cit., pp. 316 y 317.
} 
Este obra forma parte del acervo de la Biblioteca Jurídica Virtual del Instituto de Investigaciones Jurídicas de la UNAM www.juridicas.unam.mx

tiempos del Estado". 88

Casi todos estos fenómenos son prácticamente universales y propios, especialmente, de los primeros compases en procesos de democratización que intentan dejar atrás situaciones de falta de respeto por las reglas básicas de los sistemas constitucionales pero en los que la mayoría de los componentes del pueblo (cuerpo electoral) se educaron y vivieron, en sistemas con taras graves en cuanto al ejercicio real de los derechos de participación política. También los de sufragio activo y pasivo.

Uno de los temas ya clásicos, por tanto, en la jurisprudencia electoral mexicana es el de la "propaganda negra". Limitándonos a revisar los pronunciamientos del TEPJF en los últimos tiempos, podemos decir que ante la avalancha de expresiones negativas en campaña de todos los actores electorales y dados los diferentes contextos se ha afirmado, por ejemplo, que determinados promocionales (que contenían las palabras botín, chantaje, venganza, desacato, ilegal, etcétera) tenían por objeto denigrar y nada aportaban al debate político (Sala Regional de Monterrey, SM-RAP-33/2009).

Ya en la campaña para las presidenciales de 2012, destaca la SUP-RAP-386/2012, en donde por una parte, reaparecen las dificultades para probar determinadas conductas, y por otra, se vuelve a argumentar sobre el mayor sometimiento al escrutinio público de los personajes públicos (del que ya se había hablado en SUP-RAP-36/2006 y SX-JRC60/2009; sobre los casos alrededor de las presidenciales de 2006, permítaseme remitir a Torres Muro 2010, pp. 139 y ss.), sin llegar a extraer consecuencias extremas de la existencia de una campaña negra contra, como de costumbre, el candidato López Obrador.

EI TEPJF parte de la base de la necesidad de una libertad de expresión "vigorosa" que excluye, por supuesto, la censura previa (SUP-OP-13/2008) que en la CPEUM (artículo 7o.) parece prohibida solamente en el caso de la "libertad de escribir y publicar escritos". Está claro que no sería admisible, teniendo en cuenta también los instrumentos internacionales a los que México lleva tiempo adherido (por ejemplo, artículo 13 CADH: el ejercicio del derecho a la libertad de pensamiento "no puede estar sujeto a previa censura"), una interpretación literal que pretendiera que solamente en el caso de material impreso tiene vigencia la regla a la que hemos hecho referencia.

${ }^{88}$ Astudillo, César et al., op. cit., pp. 188 y 189. 
Este obra forma parte del acervo de la Biblioteca Jurídica Virtual del Instituto de Investigaciones Jurídicas de la UNAM www.juridicas.unam.mx

Un conflicto que puede ser un buen ejemplo de la "expresión vigorosa", es el que resuelve la sentencia SUP-RAP-448/2012 (caso Domino), al rechazar la imposición de la sanción porque las expresiones "sólo tratan de proporcionar la exposición y la discusión de un tema de interés nacional".

Por otra parte, el TEPJF es muy consciente de los efectos perjudiciales que ocasiona el uso de mensajes negativos como herramienta de la guerra sucia: principalmente, los de degradar la política, incitar al ciudadano a la abstención, promover el cinismo, y poner en peligro la estabilidad democrática de un país (SUP-JRC-175/2005).

Tampoco se han hecho demasiadas ilusiones respecto a las dificultades de la prueba de esas conductas reprobables, hasta el punto de que se ha dicho que del repaso de las argumentaciones del TEPJF en esta materia, en las sentencias de dicho órgano, la gran mayoría de ellas concluye en una desestimación de las propuestas de condena o anulación de las elecciones, por "no probarse con suficiencia" las posibles vulneraciones de derechos. ${ }^{89}$

No cabe duda de que los dilemas clásicos se le han presentado con toda crudeza al TEPJF. Las reacciones contra los supuestos de "propaganda negra", deben calibrarse cuidadosamente para no caer en actitudes propias de una excesiva restricción del flujo de ideas y opiniones, durante los procesos electorales que resultaría, con toda evidencia, contraproducente. Por ello, la alternativa de la "prohibición de difundir propaganda que denigre o calumnie, ha causado, y sigue causando tremendos dolores de cabeza al TEPJF a la hora de calificar las expresiones cuestionadas y difundidas, en el seno de un debate político". ${ }^{90}$

En este contexto, las reiteradas críticas, a veces muy ácidas, respecto al político mexicano que más ha sufrido y que ha reaccionado de una manera más contundente contra las prácticas de propaganda negra (López Obrador, el "peligro para México"), se han visto convalidadas por una jurisprudencia que al modo clásico ha tenido en cuenta, como ya hemos apuntado más arriba, el carácter de personaje público del mismo; objeto, por tanto, de críticas y de un escrutinio más exhaustivo por parte de la opinión (por

\footnotetext{
${ }^{89}$ Esquivel, Yessica, op. cit., p. 200; sobre la teoría de la prueba que maneja el TEPJF, en el contexto del problema de la financiación ilegal de las elecciones, véase, Torres Muro, Ignacio, “La supuesta financiación..., cit., pp. 1187 y ss.

${ }^{90}$ Esquivel, Yessica, op. cit., p. 205.
} 
Este obra forma parte del acervo de la Biblioteca Jurídica Virtual del Instituto de Investigaciones Jurídicas de la UNAM www.juridicas.unam.mx

todas, SUP-RAP-36/2006).

También hay que decir, respecto al mismo protagonista de la vida política, que, cuando se cuestionaron sus intervenciones proclamándose "presidente legítimo de México", el TEPJF llegó a la conclusión de que no estábamos ante un ejercicio ilegítimo de la libertad de expresión de sus seguidores, puesto que no denigraban al verdadero titular de ese cargo, al no contener ninguna expresión injuriosa, insultante, difamatoria o calumniosa, ni afectar al bien jurídico tutelado. Se trataba, por otra parte, de un ejercicio de dicha libertad y de la de acción política, de los partidos (PRD y PT) que sostuvieron esa campaña postelectoral de López Obrador (SUP-RAP-123/2008, y SUP-RAP-124/2008, y acumulados).

Entre los lógicos vaivenes, en los intentos de fijar claramente unos límites que no dejan de moverse con evidente flexibilidad, nos encontramos con resoluciones menos tolerantes con la crítica, como por ejemplo, las sentencias que tienen que ver con la candidata (Josefina Vázquez Mota, “Chepina”) que tuvo que en 2012 defender la gestión de los compañeros de partido que habían ocupado la presidencia de la República (Fox y Calderón, ambos del PAN).

Despedirse de ella, antes de las votaciones, agradeciéndole haber participado ("Adiós Chepina, gracias por participar"), fue considerado por el TEPJF (SUP-RAP-400/2012), como una expresión que podía influir en el ánimo de los votantes, al hacerles creer que, de cualquier forma, tal candidata no ganaría, lo cual podría generar una disminución en el número de adeptos o desánimo entre sus simpatizantes.

Para Esquivel, en este caso, "la Sala Superior mostró poca tolerancia a las críticas con las gestiones de los gobiernos anteriores", críticas que "no se salen del margen de la sana deliberación que le es exigible a un ciudadano medianamente pensante y participativo". ${ }^{91}$

Otros autores, refiriéndose también a las presidenciales de 2012 sostienen que esta vez, "la campaña negativa estuvo enfocada principalmente en contra de Enrique Peña Nieto... (que)...fue percibido como un candidato enfocado en sus propuestas y que no recurrió a la guerra sucia". ${ }^{92}$

\footnotetext{
${ }^{91}$ Ibidem, p. 218.

${ }^{92}$ Cantú, Jesús et al., op. cit., pp. 269 y 270.
} 
Este obra forma parte del acervo de la Biblioteca Jurídica Virtual del Instituto de Investigaciones Jurídicas de la UNAM www.juridicas.unam.mx

En cuanto a la regla de la norma suprema mexicana (artículo 41, fracción III, inciso C, CPEUM), que invita "en la propaganda política o electoral....abstenerse de expresiones que denigren (entre otros, también los partidos y las personas, como ya sabemos) a las instituciones", las sentencias han convalidado las críticas agudas (error, incompetencia, complicidad) al Instituto Federal Electoral (SUP-RAP-277/2009); a un candidato a gobernador ("camarilla mafiosa"; SUP-JRC-356/2010); a una institución pública que presta servicios de salud (Instituto de Seguridad y Servicios Sociales de los Trabajadores del Estado), puesto que las expresiones contenidas en el promocional (suspensión de beneficios sociales por el gobierno) no fueron denigrantes porque no existieron datos que demostraran que tales aseveraciones hayan tenido como propósito esencial denostar a una institución pública (SUP-RAP-69/2012), y por fin, a un partido en el gobierno (PRI en Tabasco) dado que los calificativos que se utilizaron (tramposo, cómplice del corrupto...) se encuentran dentro del marco de la libertad de expresión (SUP-RAP-489/2012).

Es de apreciar, también, que tanto el TEPJF como la Suprema Corte mexicana, tienen claro en una línea coincidente con lo que sucede en todos los Estados democráticos de derecho (de la que podemos poner, entre otros muchos, el ejemplo de la jurisprudencia constitucional española, que es contundente al respecto; por todas, SSTC 105/1990, del 6 de junio, FJ 6; y 49/2001, del 26 de febrero, FJ 5), que la libertad de expresión, en campañas electorales no ampara un supuesto "derecho al insulto", ya que las expresiones ofensivas no son necesarias para ejercer la crítica más o menos ponderada.

El organismo mexicano de justicia electoral se ha pronunciado en ese sentido en varias resoluciones (SUP-RAP-34/2006 y 36/2006 acumulados; SUP-RAP-009/2004; SUPJRC-288/2007; SUP-RAP 64/2008; SUP-JRC-109/2011 y SG-JRC-1219/2012). Y ello sin dejar de decir, de igual forma, que se debe permitir la crítica severa. Del examen de dichas sentencias, Esquivel concluye que el primer factor determinante es "la relevancia pública del tema tratado y el carácter de personaje político"93 del "sometido a maltrato".

Esta es una solución clásica recibida, por ejemplo, en España (por todas, SSTC 336/1993, del 15 de noviembre, FJ 5 A; 39/2005, del 28 de febrero, FJ 5; y 9/2007, del 15 de enero, FJ 5) en donde el Tribunal Constitucional ha afirmado (primera de las sentencias citadas), intentando alcanzar un cierto equilibrio, que "las personas que

${ }^{93}$ Esquivel, Yessica, op. cit., p. 225. 
Este obra forma parte del acervo de la Biblioteca Jurídica Virtual del Instituto de Investigaciones Jurídicas de la UNAM www.juridicas.unam.mx

ostentan un cargo de autoridad pública o las que poseen relieve político, ciertamente se hallan sometidas a la crítica en un Estado democrático. Pero... ello no significa en modo alguno que, en atención a su carácter público, dichas personas queden privadas de ser titulares del derecho al honor que el artículo 18.1, CE garantiza:"

La Suprema Corte mexicana sostiene también (Tesis 1\%/J. 38/2013, Décima Época, p. 538) que "dicho umbral de tolerancia deberá ser mayor solamente mientras se realicen funciones públicas o estén involucradas en temas de relevancia pública. Esto no significa que la proyección pública de las personas les prive de su derecho al honor, sino simplemente que el nivel de intromisión admisible será mayor, aunque dichas intromisiones deben estar relacionadas con aquellos asuntos que sean de relevancia pública".

Ello supone, para Esquivel, que "aunque no se reconozca abiertamente el derecho al insulto, si se está permitiendo un derecho a debatir en las mismas condiciones a pesar de lo molesto, hiriente, incluso de mal gusto y despectivas que puedan resultar las expresiones manifestadas". ${ }^{94}$

Respecto a otros pronunciamientos interesantes, en estos terrenos, de la Suprema Corte, la misma ha partido de la base de que "no sólo se encuentran protegidas las ideas que son recibidas favorablemente o las que son vistas como inofensivas o indiferentes... (puesto que)... estas son las demandas de una sociedad plural, tolerante y abierta, sin la cual no existe una verdadera democracia". ${ }^{95}$

Sin embargo, subraya -asimismo-, que "el uso de la libertad de expresión para criticar o atacar mediante el empleo de términos excesivamente fuertes y sin articular opinión, puede conllevar una sanción que no resultaría violatoria de la libertad de expresión... (La Constitución)... no reconoce un derecho al insulto a o la injuria gratuita... (se excluyen de la protección constitucional)...las frases y expresiones... absolutamente vejatorias... (es decir)...las ofensivas u oprobiosas, según el contexto...las impertinentes para expresar opiniones o informaciones, según tengan o no relación con lo manifestado... (la importancia del contexto)... estriba en que la situación política o social de un Estado y las circunstancias concurrentes a la publicación de la nota pueden

\footnotetext{
${ }^{94}$ Ibidem, p. 225.

${ }^{95}$ Tesis 1a/J. 32/2013, Décima Época, p. 540.
} 
Este obra forma parte del acervo de la Biblioteca Jurídica Virtual del Instituto de Investigaciones Jurídicas de la UNAM www.juridicas.unam.mx

disminuir la significación ofensiva y aumentar el grado de tolerancia". ${ }^{96}$

En un terreno ajeno al que acabamos de ver, se mueve el problema de la denigración y la calumnia. El TEPJF ha intentado defender, por ejemplo, el honor de las instituciones (jurisprudencia 14/2007, honor y reputación, reconocidos en la libertad de expresión) y ha construido, basándose en la Constitución y la ley, la regla de que los partidos políticos deben abstenerse de cualquier expresión ofensiva, ${ }^{97}$ con algunos casos especialmente interesantes (por ejemplo, SUP-RAP-81/2009 "sopa de letras").

También se ha combatido la imputación de delitos en el debate electoral basada en datos erróneos, y cuando no está abierto un proceso penal. Así, se ha visto una acusación carente de sustento, en SUP-RAP-135/2010, una de homicidio que no puede aceptarse como medio de lucha política y no contribuye a los fines de la discusión política-electoral, en tanto que forjadora de una opinión pública informada en SUP-RAP119/2011, otra que atribuye a un candidato (López Obrador, iqué casualidad!) la intención de promover la "vía armada" para transformar el país en SUP-RAP-323/2012, otra que conecta a políticos con la delincuencia organizada SUP-RAP-51/2013, y por fin, otra que lo hace con el "lavado de dinero"(SUP-RAP-444/2012). Pocas veces y con disensos claros (magistrada Alanís), el TEPJF ha permitido dicha imputación de delitos (por ejemplo, SUP-RAP-106/2013 y SUP-RAP-107/2013), al no apreciar que la misma sea "directa y expresa".

Del mismo modo, en México se ha planteado el problema clásico de la "veda" electoral, unos días antes de las votaciones y durante la jornada electoral, como momentos en los que se proscribe la posibilidad de hacer campaña. Los tribunales electorales han tenido que resolver diversos casos, diciendo algunas cosas interesantes, como que no era de recibo que un senador concediera una entrevista radiofónica el día previo a la jornada electoral (TEPJF; SUP-RAP-304/2009, SUP-RAP-305 y acumulados), o que la existencia de actos de protesta en periodo de veda electoral no son suficientes para anular una elección si no se demuestra su trascendencia en los resultados (Sala Regional de Xalapa SX-JRC-80/2010). Así, aparecer en la televisión, comentando como sería su gobierno si resultara favorecido por los electores, fue considerado como una irregularidad tolerable por la Sala Regional de Xalapa (SX-JRC-134/2010).

\footnotetext{
96 Tesis 1a/J. 31/2 013, Décima Época, p. 537.

97 Tesis XVIII/2009. "No a la denigración de las instituciones y a las calumnias de las personas".
} 
Este obra forma parte del acervo de la Biblioteca Jurídica Virtual del Instituto de Investigaciones Jurídicas de la UNAM www.juridicas.unam.mx

Para el día de las elecciones también existe doctrina importante como la contenida en la SUP-JRC-287/2000, en donde se sostiene que ante la presencia de propaganda electoral cerca de las casillas, y para que ello tenga consecuencias, hay que probar que la misma se colocó durante el plazo vedado, constituyendo un acto de presión sobre los votantes.

Asimismo, en la SUP-RAP-449/2012 se afirmó que no puede ampararse, en el ejercicio legítimo de las libertades de expresión e imprenta, una conducta consistente en pedir el voto para una candidata presidencial cuando uno está ejerciendo dicho derecho de sufragio, ni invitar el día de las elecciones, en una entrevista para un medio digital, a emitir el voto en un sentido de claras expresiones de apoyo a la misma candidata, ya que esa conducta "violenta" el proceso electoral.

Por otra parte, debe recordarse que en determinados códigos penales mexicanos, al enunciar los delitos electorales, ${ }^{98}$ se prevén normas parecidas a las españolas que criticamos más arriba. No hemos hecho una revisión exhaustiva pero, por ejemplo, en el de Colima (artículo 135-Bis 2, fracciones III y IX) se establecen penas de cárcel y multa, para quien "haga proselitismo o presione a los electores el día de la jornada electoral, en el interior de las casillas o en el lugar en que se encuentren formados los votantes", y para quien "haga proselitismo dentro de los tres días previos al de la jornada electoral". Desde el momento en que estamos hablando de sanciones que pueden ser de "seis meses a tres años" de prisión, estas normas merecen el mismo juicio crítico que, más arriba, nos inspiraron las españolas, previstas en la LOREG.

No se puede dejar de hacer referencia, en este apartado, a las decisiones que en general convalidaron la reforma constitucional de 2007 (nuevo modelo de comunicación electoral que intenta poner el acento en la equidad y la transparencia, limitando las posibilidades del poder económico de monopolizar el debate electoral) frente a quienes lo cuestionaron, precisamente por vulnerar la libertad de expresión.

La Suprema Corte de Justicia (acción de inconstitucionalidad 56/2008) sostuvo que se trataba de conjurar el riesgo de sufrir la influencia de los dueños o concesionarios de estaciones de radio, y canales de televisión o de otros grupos con el poder económico suficiente para reflejarlo en dichos medios de comunicación, generándose un poder fáctico contrario al orden democrático constitucional.

\footnotetext{
${ }^{98}$ Véase información, en detalle, de la Fiscalía especializada, www.pgr.org.mx
} 
Este obra forma parte del acervo de la Biblioteca Jurídica Virtual del Instituto de Investigaciones Jurídicas de la UNAM www.juridicas.unam.mx

Algunos autores han apoyado esta línea diciendo que las nuevas reglas "en ningún momento cancelaron la libertad de expresión ni constituyen una forma de censura previa... (tratándose de)... la incorporación de las premisas del modelo de comunicación política asentado en gran parte de las democracias consolidadas europeas". ${ }^{99}$

Ese mismo sector de la doctrina mexicana ha sido contundente en la defensa del modelo adoptado, afirmando por ejemplo que "está justificado en parte en el modelo liberal al evitar daños a otros, de un lado, y en parte en el democrático, al facilitar la participación de todos en condiciones de equidad en el debate y la deliberación, así como en la toma de decisiones razonadas e informadas". ${ }^{100}$

No ha dejado de señalarse que "las razones de oposición a las nuevas reglas", por parte de "los concesionarios privados de la radiodifusión, encabezados por las principales televisoras del país", probablemente tengan relación con el hecho de "ver cancelado un millonario negocio por la venta de espacios en las campañas electorales". ${ }^{101}$

EI TEPJF, por su parte, tuvo que decidir sobre las alegaciones de vulneración de la libertad de expresión, por dicho modelo, basándose en la literalidad de algunos instrumentos internacionales de protección de derechos humanos. En dichos pleitos afirmó (SUP-JDC-1749/2012, y SUP-JDC-1774/2012) que éstos no pueden aplicarse desconociendo las restricciones a esos mismos derechos, establecidas expresamente en la CPEUM.

La reforma, por otro lado, y para el Tribunal Electoral, en cuanto se trata de garantizar la equidad en la contienda electoral y la restricción de supuestos derechos se limita a la regulación de la compra de promocionales, o espacios en radio y televisión. Por ello, no va en contra de la deliberación política en el proceso electoral sino que contribuye, y garantiza, el desarrollo de los comicios, eliminando injerencias externas e indebidas. En síntesis, no es contraria ni a otros contenidos de la CPEUM, ni al artículo 13 de la $\mathrm{CADH}$.

\footnotetext{
${ }^{99}$ Astudillo, César et al., op. cit., pp. 182 y 186.

${ }^{100}$ Ibidem, p. 182.

101

Calleja Gutiérrez, Aleida Elsi et al., “Perspectivas y evolución del modelo de comunicación político electoral", Revista Mexicana de Derecho Electoral, núm. 4, 2013, p. 228.
} 
Este obra forma parte del acervo de la Biblioteca Jurídica Virtual del Instituto de Investigaciones Jurídicas de la UNAM

Por lo que respecta a la atribución a determinadas fuerzas electorales de actitudes o hechos, que las implican en situaciones de violencia, por desgracia no infrecuentes en México, el TEPJF ha sostenido (SUP-RAP-116/2010, por ejemplo) que no es admisible relacionar a un candidato con actividades ilícitas, si dicha imputación directa es injustificada, porque no existe una sentencia ejecutoriada y firme que la sustente. Nos hallaríamos ante una calumnia al atribuir al candidato sin prueba fehaciente y maliciosamente, actos y conductas que pueden resultar deshonrosas y delictivas.

Por el contrario, los resultados de una elección rodeada de significativos episodios de violencia (según los recurrentes, amenazas a candidatos, homicidio de un presidente municipal, mensajes de intimidación, incidentes el día de la jornada electoral) fueron convalidados (SUP-JRC-6/2012; SUP-JRC-7/2012 y SUP-JRC-8/2012) sosteniendo que no se demostró ni cuantitativamente, ni cualitativamente la existencia de violencia generalizada. Tampoco se dio un impacto, igualmente general, del temor al libre ejercicio del sufragio. Quizás es que haya que reconocer que "los fenómenos de inseguridad rebasan por mucho los alcances de la justicia electoral". ${ }^{102}$

Ha resultado difícil mantener la tolerancia cero con las acusaciones de conexión con los violentos, pues se ha razonado (por ejemplo, SUP-RAP-251/2012 y SUP-RAP-256/2012) que las expresiones críticas son de tipo general, y las referencias a un partido político concreto no parecen evidentes (voto particular de Alanís, que considera que está claro que la descalificación, en promocionales del PAN, estaba dirigida al PRI; y voto particular de Galván, que afirma que se denigra al PRI y se calumnia a sus candidatos).

Las afirmaciones, en la campaña electoral de 2012, sobre la conexión de un candidato a la presidencia (Peña Nieto) con el crimen organizado (bandas de delincuencia organizada como los "Zetas") y la corrupción, y su tolerancia con conductas ilícitas, son expresiones que no son de recibo para el TEPJF, ya que merecen todo reproche social y legal (SUP-RAP-319/2012). La conclusión de otro proceso es el acuerdo de multar a quienes (PAN) presentan al PRI y a su candidato Peña Nieto, al lado de delincuentes y traficantes de droga (SUP-RAP-387/2012), desde el momento en que ciertas afirmaciones ("Ios Zetas controlan Veracruz", o "acusado de protección al narco en Estados Unidos") van más allá de una exposición de ideas y opiniones fuertes, y vigorosas, que sí son permisibles.

${ }^{102}$ Esquivel, Yessica, op. cit., p. 232. 
Este obra forma parte del acervo de la Biblioteca Jurídica Virtual del Instituto de Investigaciones Jurídicas de la UNAM

La normativa constitucional mexicana pretende limitar, durante la campaña, la llamada "propaganda gubernamental". Así, el artículo 41, fracción III, inciso C, de la CPEUM dispone que: "durante el tiempo que comprendan las campañas electorales federales y locales, y hasta la conclusión de la respectiva jornada comicial, deberá suspenderse la difusión en los medios de comunicación social de toda propaganda gubernamental... Las únicas excepciones a lo anterior serán las campañas de información de las autoridades electorales, las relativas a servicios educativos y de salud, o las necesarias para la protección civil en casos de emergencia".

Y en el artículo 134 CPEUM se afirma que: "la propaganda, bajo cualquier modalidad de comunicación social, que difundan como tales los poderes públicos... o cualquier ente de los tres órdenes de gobierno deberá tener carácter institucional y fines informativos, educativos o de orientación social. En ningún caso esta propaganda incluirá nombres, imágenes, voces o símbolos que impliquen promoción personalizada de cualquier servidor público".

Lo difícil ha sido fijar en la doctrina del TEPJF, cuándo nos hallamos ante propaganda de los poderes públicos. La casuística es variada. Desde el dilema de si enviar cartas a los contribuyentes para agradecer el cumplimiento de las obligaciones tributarias pero en periodo electoral, es admisible (SUP-RAP-196/2012; SUP-RAP-221, y 222/2012; SUP-RAP234/2012), al supuesto apoyo al PAN, entonces en el gobierno, en campañas de la Lotería Nacional, la Secretaría de Turismo, el Banco de México, los Festejos del Bicentenario, etcétera, en el que la Sala Superior convalidó las mismas, razonando que constituyen una actividad meramente institucional que posibilita el cumplimiento cabal de las tareas del Estado (SUP-RAP-57/2010).

Sin embargo, en ningún caso se ha dicho que una campaña de la Secretaría de Gobernación en la que pretendía otorgar recompensas por denunciar a sujetos vinculados a delitos de extorsión y delincuencia organizada, no estaba vinculada a ningún aspecto de "educación" (recuérdense los artículos 41, fracción III, inciso C y 134 CPEUM), y no entraba dentro del desarrollo que el Consejo General del IFE, en una determinada normativa, había hecho de la Constitución (de todas las sentencias, en ese sentido, ver SUP-RAP-54/2012 y acumulados).

Por lo que respecta a las informaciones periodísticas, que puedan favorecer a algún candidato, al referirse a sus logros como gestor, tenemos varios casos interesantes. El 
Este obra forma parte del acervo de la Biblioteca Jurídica Virtual del Instituto de Investigaciones Jurídicas de la UNAM www.juridicas.unam.mx

primero, el de las SUP-RAP-290/2012 y SUP-RAP-482/2012, en las que la noticia, sobre determinadas obras públicas en el Distrito Federal, se consideró un caso de ejercicio periodístico, ajeno a contraprestación económica alguna.

Más estricto se mostró el TEPJF (SUP-RAP-318/2012) con declaraciones del secretario de Economía (del PAN), con duras críticas al PRI ("políticos ladrones"). No obstante, en voto particular, varios magistrados (Luna Ramos, Carrasco Daza y Nava Gomar) consideraron que dichas opiniones podían estar bajo el amparo de la libertad de expresión, y no era posible estimar que violentaran el principio de equidad en la contienda electoral. La mayoría consideró que, dado que eran expresiones del alto cargo, el supuesto de propaganda gubernamental se actualizaba inevitablemente.

Las declaraciones de servidores públicos -interviniendo en la contienda electoralhan sido enjuiciadas por los tribunales. En la SUP-JRC-264/2004 un presidente municipal adelantó una fiesta local para hacer proselitismo a favor de su esposa, que era candidata, y envió cartas a los ciudadanos, invitando a dar continuidad al gobierno del PAN. La Sala Superior no consideró probados los agravios aducidos ni el uso de recursos públicos.

El gobernador de Sonora vio cuestionadas sus declaraciones, con motivo de un incendio en una guardería pero el TEPJF consideró que no había difundido programas, acciones, obras o logros del gobierno, y por ello, no constituía propaganda electoral (SUP-RAP-307/2009). La Sala Regional de Xalapa entendió que aparecer siendo gobernadora en un cierre de campaña de una candidata, en día inhábil, y levantarle los brazos en señal de victoria, no tenía trascendencia y no entrañaba inducción sobre el electorado (SX-JRC-45/2010).

Con cierta valentía, el TEPJF (Sala Superior; SUP-RAP-119/2010 y SUP-RAP-125/2010) dictaminó que el presidente de la República puede ser denunciado y llamado a un procedimiento administrativo sancionador, en materia electoral, además de ser susceptible de ser declarado responsable de incumplir con una prohibición constitucional (votos particulares de Galván Rivera -los servidores públicos no pueden ser sancionados por el IFE - y González Oropeza —el Presidente no es responsable por ilícitos electorales-). Los mensajes de la presidencia durante la jornada de reflexión en comicios locales vulneraron, en este caso, el artículo 41 CPEUM.

La posible inviolabilidad de los parlamentarios mexicanos, en este terreno de la propaganda gubernamental, fue negada en el caso en el que el grupo parlamentario del 
Este obra forma parte del acervo de la Biblioteca Jurídica Virtual del Instituto de Investigaciones Jurídicas de la UNAM www.juridicas.unam.mx

PAN en el Congreso de la Unión pretendió difundir imágenes para favorecer a su candidato en Chihuahua. Considerando que se hacía proselitismo se condenó al PAN, como responsable por culpa in vigilando de lo hecho por su fracción (SUP-RAP-229/2009).

No se sancionó a un servidor público que recibió como tal cobertura de los medios, porque no se pudo apreciar mediante pruebas idóneas que corroboraran la utilización de recursos públicos destinados a promover su imagen (SUP-JRC-130/2010).

En cuanto al problema de los informes "de labores o de gestión" de los servidores públicos, la Sala Superior (SUP-OP-25/2008) dictaminó que la prohibición de difundir informes anuales de ese tipo, donde ejerzan su responsabilidad aquéllos, no infringe los artículos 41 y 134 CPEUM. Sin embargo, (en SUP-RAP-75/2009) se anularon sanciones del IFE a legisladores por contratar, fuera de del periodo de precampaña (para el magistrado Galván Rivera las limitaciones sólo deben abarcar la etapa de campaña electoral) o campaña, mensajes para dar a conocer sus actividades que no constituyen propaganda electoral.

No obstante, tanto Peña Nieto, cuando era gobernador del Estado de México, como el gobernador de Puebla (Moreno Valle Rosas) y el presidente Calderón, vieron cómo la difusión de sus informes fue sancionada como propaganda gubernamental inadmisible (SUP-RAP-24/2011; SUP-RAP-260/2012; y SUP-RAP-314/2012, respectivamente).

Es preciso hacer referencia, también, a los intentos de limitar la apropiación indebida de programas sociales; es decir, usar los éxitos de los mismos para apoyar a candidatos. El Tribunal Electoral ha sido bastante reticente en entrar en ese asunto, razonando que no es antijurídico que un partido tenga que excluir de su discurso general los logros obtenidos (SUP-RAP-21/2009). En SUP-JRC-64/2011 y SUP-JRC-65/2011, se cuestionó la aplicación del artículo 265 del Código Electoral del Distrito Federal, porque la propaganda, sobre los aciertos de una administración, está permitida como ejercicio de la libertad de expresión en el debate político-electoral.

EI TEPJF ha dictado resoluciones sobre los actos anticipados de precampaña (SUP-JRC96/2009; SUP-JRC-97/2009; SUP-JRC-99/2009 y SUP-RAP-15/2012), subrayando que no tienen por objetivo promocionar plataformas electorales ni obtener el voto. También, sobre los actos anticipados de campaña tanto de la Sala Superior como de las regionales, en las que se revisan los casos en los que se ha intentado posicionar al partido o candidato, anticipadamente (SUP-JRC-19/1998; SUP-JRC-RAP-70/2006; SUP-RAP-39/2012; 
Este obra forma parte del acervo de la Biblioteca Jurídica Virtual del Instituto de Investigaciones Jurídicas de la UNAM www.juridicas.unam.mx

SUP-RAP-253/2012； SG-RAP-58/2009； SG-RAP-59/2009； SM-JRC-17/2013； y ST-JDC2373/2012). “Sobre el tema de regular... (dichos actos)... las autoridades electorales mexicanas han sido muy rigorosas". ${ }^{103}$

La adquisición indebida de tiempos de radio y televisión es otro problema clásico para las autoridades electorales mexicanas. Su trascendencia viene demostrada por el hecho de que "la televisión es el medio dominante de información política en términos absolutos, para todos los grupos educativos y de ingresos en México". ${ }^{104}$ Con independencia de remitir a quienes han realizado una evaluación del funcionamiento efectivo, del modelo adoptado en la reforma constitucional de 2007, respecto a la distribución de las posibilidades de emitir mensajes electorales, ${ }^{105}$ está claro que ésta era una de las apuestas más complicadas de la misma. Aquélla que si se consolida, como parece que ha ocurrido, tendrá consecuencias muy importantes en el futuro, para el funcionamiento de los procesos electorales en México.

El respeto de las estrictas reglas del artículo 41, fracción III, incisos A y G, CPEUM ("Ios partidos políticos en ningún momento podrán contratar o adquirir... tiempos en cualquier modalidad de radio y televisión. Ninguna otra persona física o moral... podrá contratar propaganda en radio y televisión dirigida a influir en las preferencias electorales...), ha hecho que se persigan los promocionales proselitistas, pagados o no, que quedaron fuera del control del IFE (SUP-RAP-198/2009), la adquisición por terceras personas de tiempos en radio y televisión, planteándose el problema de las dificultades para acreditar el vínculo entre el candidato y el sujeto que contrata la propaganda (SUPRAP-6/2010), o la difusión de promocionales en una cadena nacional, caso en el que se consideró que no se probó la vulneración de la normativa electoral (SUP-RAP-427/2012).

Quizás la controversia más sonada en este terreno fue la de los "calzoncillos del boxeador del PRI", los lució en una pelea en Las Vegas (Estados Unidos) retransmitida a todo México en horario estelar. En las SUP-JRC-6 a 8/2012, la Sala Superior (contra el criterio de la regional de Toluca, ST-JRC-117/2011) consideró que no hubo propaganda

\footnotetext{
${ }^{103}$ Ibidem, p. 262.

${ }^{104}$ Cantú, Jesús et al., op. cit., p. 262.
}

105

Alcocer Villanueva, Jorge, “Evaluación integral del modelo de acceso a radio y televisión en materia electoral", Revista Mexicana de Derecho Electoral, núm. 4, 2013, pp. 155 y ss. 
Este obra forma parte del acervo de la Biblioteca Jurídica Virtual del Instituto de Investigaciones Jurídicas de la UNAM www.juridicas.unam.mx

electoral, no se lesionó el principio de equidad en la contienda, y no hubo conexiones con los nombres de los candidatos, por lo que no procede declarar la nulidad de la elección.

En cuanto a las entrevistas en radio y televisión, se permiten si constituyen labor de información, siempre que no constituyan propaganda encubierta en fraude de ley, como pudo suceder en SUP-RAP-22/2010, en la que la candidata era entrevistada por su esposo; o en SUP-RAP-589/2010, en donde una aspirante a gobernadora pretendió que se emitiera una reportaje sobre su "historia de superación y éxito". Pero en SUP-RAP40/2012 se resolvió que una entrevista, a esa misma candidata, no fue un acto de simulación para conculcar la normativa electoral, ni promoción personalizada sino una actividad periodística. Sin embargo, una entrevista realizada a un candidato durante la transmisión de un partido de fútbol, en horario estelar, constituye un fraude de ley y acto de propaganda electoral (SUP-RAP-234/2009).

En la SUP-RAP-33/2013 se aborda el tema de los "flashes" informativos que dan noticia de las actividades de servidores públicos y candidatos, fuera del marco de la ley electoral, por lo que se aprecia violación al principio de equidad y neutralidad. Sobre la incompatibilidad del estatus de analista, reportero o comentarista con la condición de precandidato, o candidato, en elecciones, ha sido afirmada en la normativa electoral y en la jurisprudencia (SUP-RAP-280/2009, en donde, no obstante, con voto particular de Galván Rivera se considera que prevalece la libertad de expresión; SUP-RAP-547/2011 y SUP-RAP-572/2011, en donde se habla de "indebida adquisición de tiempo"; SUP-RAP548/2011, que se refiere a difusión de opiniones en medios masivos y SUP-RAP-549/2011, donde se subraya que la candidata se ha presentado a la ciudadanía al transmitirse su opinión en un noticiero) para evitar que aquellos gocen de una posición de ventaja sobre sus competidores.

Respecto a los debates ha sido controvertida tanto su organización por el IFE, de acuerdo con los artículos 70 y 73 del Código Federal de Instituciones y Procedimientos Electorales, en adelante Cofipe (SUP-RAP-94/2012; SUP-RAP-93/2012 y SUP-JDC335/2012), como las limitaciones que prevén esas normas (máximo dos debates, que era lo que se cuestionaba), que han de ser respetadas para no violentar los principios de 
Este obra forma parte del acervo de la Biblioteca Jurídica Virtual del Instituto de Investigaciones Jurídicas de la UNAM

legalidad y certeza (para profundizar estos problemas. ${ }^{106}$

Los debates organizados sin dicho control deben, también, respetar la prohibición de compra de espacios. Así, la SUP-RAP-459/2011 aprecia que no estábamos, en unos organizados en Nayarit, ante una actividad periodística o un ejercicio de la libertad de expresión. Se trataba de nuevo, ante una adquisición indebida de tiempos en televisión y una, también indebida, difusión de propaganda política o electoral, gratuita.

Partiendo de la base de la prohibición de contratar directa o indirectamente propaganda en el extranjero (artículo 49 Cofipe), el TEPJF se ha mostrado estricto con las solicitudes de hacer propaganda electoral fuera de México o dentro de los estados fronterizos, que pudieran captarse en otros países, pues los mensajes de las autoridades locales sólo pueden ser transmitidos en estaciones de radio y televisión, con cobertura en la entidad federativa en que tengan competencia (SUP-RAP-4/2012). Eso no deja de provocar problemas con la promoción del voto entre los emigrados (artículos 1, 9, 104 del Cofipe).

Por ello, es importante destacar, cuando nos acercamos a la conclusión de este apartado, la resistencia de los medios de comunicación mexicanos en asumir todas las consecuencias del modelo de comunicación política establecido por la reforma constitucional de 2007, con sonados incumplimientos, que dieron lugar a sentencias con las correspondientes sanciones (SUP-RAP-40/2009; SUP-RAP-64/2010; SUP-RAP-214/2010; SUP-RAP-69/2013; SUP-RAP-70/2013 y SUP-RAP-88/2012). La oposición a las reglas que prevén la adquisición gratuita de espacios en radio y televisión, que acabó con un buen negocio de las emisoras, se convirtió pronto en "una lucha encarnizada" en la que "Ios medios se convirtieron de facto en los principales antagonistas de esta reforma". ${ }^{107}$

La identificación de los candidatos también ha tenido su importancia en la jurisprudencia electoral. Así, en la SUP-RAP-38/1999 se acordó excluir la fotografía de un candidato presidencial en las boletas pero, en la SUP-JDC-911/2013, el TEPJF permitió incluir en las mismas el sobrenombre del candidato.

Por otra parte, para México la revolucionaria entrada en el juego electoral de candidaturas independientes (reforma constitucional del 9 de agosto de 2012) ha

106

Astudillo, César et al., op. cit., pp. 208-210.

${ }^{107}$ Esquivel, Yessica, op. cit., p. 302. 
Este obra forma parte del acervo de la Biblioteca Jurídica Virtual del Instituto de Investigaciones Jurídicas de la UNAM www.juridicas.unam.mx

provocado sentencias sobre la atribución equitativa a las mismas de tiempos de radio y televisión, en un acuerdo del Instituto Electoral de Quintana Roo (SUP-RAP-64/2013), y en otro del mismo órgano de Zacatecas (SUP-RAP-56/2013), que han sido convalidados.

Finalmente, cabe hacer referencia a las decisiones que empiezan a responder a los desafíos de las nuevas tecnologías de transmisión de mensajes, también políticos y electorales. Al evaluar las relaciones entre medios de información y preferencia electorales se ha afirmado que "el uso de Internet está más relacionado con la edad y nivel socioeconómico que con la afiliación o preferencia partidista", y que este instrumento "-en especial las redes sociales- irrumpió en la campaña presidencial de 2012 como un fuerte medio de comunicación que compitió con la televisión"108 y este es un hecho que ni la normativa electoral ni los órganos de garantía de estos procesos pueden desconocer.

En la SUP-RAP-153/2009, el Tribunal se encontró con obstáculos para probar la autoría del acto de colocar contenidos ofensivos en Youtube. En la SUP-RAP-249/2011, las manifestaciones difundidas en Facebook, fueron consideradas como amparadas por la libertad de expresión. La SUP-RAP-268/2012 dictaminó que la emisión de "Tweets" y el hecho de colgar una entrevista en Youtube, no pueden calificarse, tras el análisis del contexto informático, como actos anticipados de campaña. Dado que, los medios de convicción aportados (notas periodísticas, videos difundidos por Internet), no encuadran en la definición de propaganda electoral, aunque los mismos pudieran ser calumniosos y denigratorios, la SUP-JDC-1805/2012 revoca una resolución del Tribunal Electoral de Jalisco, que sancionaba con una multa a los responsables de la difusión de esos materiales.

Tras este repaso a las actividades, en materia de libertad de expresión electoral, de los diferentes órganos de garantía en México, creo que resulta en exceso pesimista concluir que "en el contexto de la pluralidad política y los gobiernos divididos, el problema fundamental consiste en regular a la multiplicidad de actores que, en su búsqueda por el poder, están dispuestos a infringir la normativa electoral e incluso a romper con los esquemas elementales de una contienda democrática". ${ }^{109}$

${ }^{108}$ Cantú, Jesús et al., op, cit., p. 268.

109

Sonnleitner Willibald et al., “La paradoja mexicana: de la evaluación de la calidad técnica de las elecciones de 2012, al debate sobre la calidad del voto y a la cuestión de la legitimidad democrática", Revista 
Este obra forma parte del acervo de la Biblioteca Jurídica Virtual del Instituto de Investigaciones Jurídicas de la UNAM www.juridicas.unam.mx

No seré yo quien les enmiende la plana a prestigiosos analistas mexicanos, como los que acabo de citar. Tampoco me considero un ingenuo, con la venda en los ojos frente a los problemas muy serios y, a veces, tremendamente radicales (de vida o muerte, nada menos) que rodean, todavía, los procesos electorales en México; pero, en mi opinión, si ponemos el rendimiento del sistema en el contexto de una historia muy deficiente, de todos conocida y de las realidades que se dan en otros países de similar nivel de desarrollo social y económico, parece que podemos afirmar que se progresa en la dirección correcta.

No hay que pretender, por supuesto, la perfección absoluta que no es cosa de este mundo sino que sigamos avanzando en la inacabable tarea de dotar a la ciudadanía de instrumentos de participación cada vez mejores, y persiguiendo el ideal de construir sociedades verdaderamente democráticas, también en el difícil ámbito iberoamericano. En ese marco, y con todos sus posibles defectos, la labor en México de los institutos y los tribunales electorales, en materia de libertad de expresión en las campañas, ha conseguido corregir las desviaciones más llamativas. Debemos alegrarnos por ello, sin que eso suponga bajar la guardia en una tarea de razonable complejidad, y en la que solamente se puede avanzar contrastando continuamente las reglas constitucionales y legales, con una práctica debe irse perfeccionando cada día.

\section{CONCLUSIÓN. ¿PUEDE SACARSE PARTIDO A LA “EQUIDAD” Y A LA "IGUALDAD DE OPORTUNIDADES" EN MATERIA ELECTORAL?}

De todo este repaso a la problemática de la libertad de expresión, en los procesos electorales, con especial énfasis en los casos mexicano y español, lo más importante es que pretendemos, en este terreno, acercarnos al ideal de que los actores de los mismos estén en una parecida situación de partida. Eso es lo que garantiza el correcto desarrollo de las elecciones, de modo que sus resultados lleven a los órganos, que ejercen el poder, a la voluntad de los ciudadanos.

Está claro que cuando se procede a poner en marcha los mecanismos de representación, se consigue, como mucho, alcanzar un retrato aproximado de lo que son los deseos de los electores. Nos encontramos siempre, para empezar, con los que podrían denominarse "condicionamientos técnicos" (sistema electoral, circunscripciones, 
Este obra forma parte del acervo de la Biblioteca Jurídica Virtual del Instituto de Investigaciones Jurídicas de la UNAM

etcétera), que irremediablemente distorsionan la expresión de aquéllos.

Aunque, siendo conscientes de estos problemas, también lo somos de la necesidad de ir avanzando poco a poco, como se ha venido haciendo en los Estados liberaldemocráticos desde hace ya muchos años, en la tarea de perfeccionar la regulación jurídica de esos instrumentos.

Todo ello sin considerarnos, desde luego, tan inocentes como para pensar que esta técnica de control social que es el derecho, conocida por sus evidentes limitaciones, puede ser suficiente para resolver todos los problemas que se presentan.

Muchos de ellos han desaparecido cuando han cambiado rasgos sociales decisivos en las sociedades que estaban en la base de dichas formas políticas. Factores como una mejor cultura política, el desarrollo económico y la mejora de la educación, son, sin duda, muy importantes.

Conviene, por tanto, no limitarse a modificaciones normativas relativamente sencillas, puesto que no requieren más que la capacidad de manejar el boletín (gaceta) oficial correspondiente. Es preciso tener en cuenta que la, mucho más difícil, labor de incidir sobre las circunstancias de la vida de los electores es la que provoca los verdaderos cambios en profundidad, que sólo se consolidan lentamente pero que, a veces, adquieren la condición de definitivos.

Partiendo de esa base, es conocido que muchos se han planteado como meta de las normas electorales, la de alcanzar la "equidad" o la "igualdad de oportunidades" en unas elecciones libres. Se intenta que todos los actores que participen en las mismas se encuentren, si no en una situación de imposible igualdad, sí en una que les permita durante dichos procesos competir con posibilidades de alcanzar los resultados que pretendan.

Por ejemplo, uno de los clásicos modernos, en estos temas electorales, puso de manifiesto en su momento que, entre los "principios formales" de las "elecciones competitivas" se halla la "igualdad de oportunidades, que deriva del principio jurídico de la igualdad, que se debe asegurar especialmente en el campo de la propaganda electoral (candidatura y lucha electoral), y que también sirve como criterio del derecho electoral". ${ }^{110}$

${ }^{110}$ Nohlen, Dieter, op. cit., p. 23. 
Este obra forma parte del acervo de la Biblioteca Jurídica Virtual del Instituto de Investigaciones Jurídicas de la UNAM www.juridicas.unam.mx

Respecto al primer concepto, el de "equidad", ha quedado demostrado por quien ha hecho el examen más exhaustivo en lengua castellana del concepto, que "no estamos ante una noción unívoca sino ante una idea multívoca y polifacética". ${ }^{111}$

Por ello, no tendría sentido adentrarnos en la historia del concepto ("Epieikeia", griega, "equitas" romana, la interpretación cristiana, etcétera) ni en sus variedades en el espacio ("equity" anglosajona, equidad en los sistemas romano-germánicos, etcétera). Pero sí debemos recordar, puesto que puede ser útil en derecho electoral, que la misma supone "tanto como lo más igual, lo más proporcional", porque "es... una idea de igualdad y proporción lo que impregna el afijo equi... (y)... cuando a éste se yuxtapone el sufijo "dad", ello eleva, en nuestro idioma, el contenido ideológico de la raíz al grado superlativo". ${ }^{112}$

Repasar las definiciones presentes en los diccionarios españoles más significativos, creemos que orienta en nuestros afanes, puesto que allí se habla, por una parte, de "moderación en el rigor del uso de las leyes" y de mirar "más a la intención del legislador que a la letra y rigor de la ley", ${ }^{113}$ o de "justicia natural, por oposición a la letra de la ley positiva". ${ }^{114}$

No hay que descartar ese uso benevolente del derecho, pero nos parece que lo más necesario, en las campañas electorales, no es tanto eso como la "igualdad y rectitud" ${ }^{115} \mathrm{y}$ la "disposición del ánimo que mueve a dar a cada uno lo que merece". ${ }^{116}$

Partiendo de que estamos ante una competición especialmente importante para la vida del Estado democrático, la misma no puede estar falseada, y es preciso ser estrictos en la tarea de conseguir la existencia de reglas del juego claras, que permitan que la batalla entre los contendientes se aleje lo más posible de ser un tongo impresentable.

\footnotetext{
111 Falcón y Tella, María José, Equidad, derecho, y justicia, Madrid, Ramón Areces, 2005, p. 28; versión inglesa, Falcón y Tella, María José, Equity and Law, Leiden/Boston, Martinus Nijhoff, 2008.

${ }^{112}$ Falcón y Tella, María José, Equidad, derecho..., cit., p. 129.

${ }^{113}$ Diccionario de Autoridades, 1732, www.rae.es.

${ }^{114}$ Diccionario de la Real Academia de la Lengua Española, 22a. ed., 2001, en la misma página web, acepción 3 del vocablo "equidad".

115 Diccionario de Autoridades, 1732.

116 Diccionario de la Real Academia de la Lengua Española, acepción 5 del vocablo "equidad".
} 
Este obra forma parte del acervo de la Biblioteca Jurídica Virtual del Instituto de Investigaciones Jurídicas de la UNAM www.juridicas.unam.mx

Solía decir don Eduardo García de Enterría (1923-2013), insigne iuspublicista liberal español recientemente fallecido, (lo que escuché varias veces en sus seminarios de los miércoles en la Complutense) que, en realidad, no había nada más regulado que el mercado, lo que parece una paradoja. Regulado, evidentemente, para favorecer el libre juego de las fuerzas económicas, sin que se produzcan situaciones que limiten la competencia.

En España, como en muchos países de "economía social de mercado" (artículo 38, $\mathrm{CE})^{117}$ tienen ese objetivo algunos organismos especialmente poderosos (ahora, la Comisión Nacional de los Mercados y de la Competencia; Ley 3/2013, del 4 de junio).

Con los procesos electorales pasa lo mismo. Si queremos unos reales y adecuados, debemos hacer una normativa estricta en la corrección de las posibles tareas contrarias a que nos hallemos en una contienda sana, y que fomente el ¿"versallesco"? ("afectadamente cortés", según la acepción segunda del Diccionario de la Real Academia de la Lengua Española) ${ }^{118}$ enfrentamiento, con el objetivo de conseguir los votos de los ciudadanos. En este terreno la equidad, por tanto, debe ser entendida como una guía para que el derecho electoral ponga a todos en una situación en la que les sea posible competir, sin trabas, por el favor del cuerpo electoral.

Junto a este concepto de equidad, otro frecuentemente utilizado, cuando se habla de la regulación de las elecciones, es el de "igualdad de oportunidades". Quien lo ha estudiado más a fondo en el ámbito hispanoamericano, empieza por reconocer que es "uno de los conceptos más ambiguos que podemos encontrar en el mundo del Derecho", ${ }^{119}$ pero aun así lo proyecta sobre la legislación electoral, afirmando que del mismo se derivan "limitaciones de la actuación de los competidores electorales... (y)... prestaciones públicas tendentes a mejorar la visibilidad de las alternativas políticas. ${ }^{120}$

También "un mandato de estricta neutralidad de los poderes públicos en la campaña

117

De Juan Asenjo, Oscar, La Constitución económica española, Madrid, CEC, 1984, pp. 63 y ss.

118 Véase, www.rae.es.

119 Sánchez Muñoz, Oscar, op.cit., p. 11; en esta monografía la visión general del asunto se contiene en las pp. 11-90.

${ }^{120}$ Ibidem, p. 71. 
Este obra forma parte del acervo de la Biblioteca Jurídica Virtual del Instituto de Investigaciones Jurídicas de la UNAM

electoral" ${ }^{121}$ combinado, en lo que a nosotros aquí nos interesa, con "limitaciones a la publicidad electoral de pago... la exigencia de un tratamiento informativo equitativo para las diferentes candidaturas durante los procesos electorales... [y]... el sometimiento de la actividad de los medios a un control por parte de autoridades administrativas independientes". ${ }^{122}$

Por lo que respecta a la libertad de expresión y los problemas de "propaganda negra", nos parece que los principios de equidad e igualdad de oportunidades, deben proyectarse en dos planos.

El primero, la existencia de una normativa completamente intolerante con los fenómenos de este tipo. Tanto por lo que se refiere a la legislación de distintos niveles como a la jurisprudencia de los tribunales, que la interpreta cuando los mismos se presentan ante un Poder Judicial que debe tener muy presente la importancia de perseguirlos sin desmayo. Y ello porque vician irremediablemente el procedimiento, de selección de los ocupantes de los cargos públicos, propio de una democracia de masas.

El segundo, conectado con el anterior, la previsión de mecanismos ante autoridades independientes $o$ ante jueces y tribunales, que permitan reaccionar de una manera lo más rápida posible, y con contundencia. Así, el que vulnere la regla del juego de que, en la crítica de las posiciones de los adversarios, en una campaña electoral (perfectamente legítima cuando, incluso con dureza, hace ver los defectos de sus propuestas o de su trayectoria previa) no se pueden sobrepasar los límites de la falta de veracidad, y el respeto a los otros contendientes. Sobre todo, no son admisibles los insultos ni las descalificaciones gratuitas.

Es preciso que el infractor no obtenga ningún rédito de estas actitudes sino más bien un castigo ejemplar, que restaure la situación previa a estas actividades reprochables. Las soluciones a aplicar hay que dejarlas a cada ordenamiento concreto, como es lógico, pues deben responder a las diferentes tradiciones y realidades sociales. Conviene ser muy conscientes, en todo caso, de que si este problema no se controla, estaremos ante un falseamiento, una verdadera devaluación del mecanismo más importante para la provisión de puestos en los poderes públicos en un Estado democrático: unas elecciones

${ }^{121}$ Ibidem, p. 77.

${ }^{122}$ Ibidem, p. 83. 
Este obra forma parte del acervo de la Biblioteca Jurídica Virtual del Instituto de Investigaciones Jurídicas de la UNAM www.juridicas.unam.mx

libres que si no pueden ser "perfectas", sí tienen que ser al menos, "auténticas", como dice, expresando los deseos de toda una sociedad, el artículo 41 de la Constitución mexicana.

Dos lecciones, por tanto, de lo dicho hasta ahora. La primera, que nuestros problemas son los típicos del equilibrio entre la libertad de expresión y otros derechos, y valores constitucionales, agravados por las especiales características de los procesos electorales, en los que todo pasa a velocidad de vértigo, y en los que hay que permitir un debate lo más rico posible pero sin vulnerar principios básicos en toda competición política, como el de que el insulto (no, por supuesto la crítica dura, incluso acerba) debe estar excluido.

La segunda, que es imposible elaborar para sostener los fallos de los órganos de control, una teoría cerrada y completa, sobre estos asuntos. A lo más que podemos aspirar es a que se diseñen principios generales que orienten la labor de aquéllos. Por tanto, es preciso reconocer que las respuestas habrán de elaborarse caso por caso, y dependiendo de las circunstancias de los supuestos que se nos presenten. No hay que escandalizarse por ello. Es lo que pasa en muchos sectores del ordenamiento, porque al fin y al cabo, el derecho y las resoluciones que en él se apoyan, no están para proponer bellos y complejos entramados doctrinales, sino para pacificar conflictos. Los académicos que pierdan eso de vista estarán construyendo en el aire; es decir, harán curiosos edificios totalmente inservibles; o, lo que es peor, que sirvan al poder para ocultar la realidad, como ha sucedido tantas veces en el pasado.

Las directrices más liberales pudieran quizás basarse en el uso de la normativa penal y la correspondiente jurisprudencia, sobre los delitos del abuso de la libertad de expresión (injurias y calumnias), puesto que existe sobre ellos, en algunas naciones, una teoría muy desarrollada a la que acompaña una larga historia de aplicación de los tipos previstos en los códigos. El único problema es que en México, esta vía de protección de derechos y valores, frente a los excesos en el ejercicio de la expresión, está cerrada en muchos estados miembros de la Federación, desde el momento en que, como ocurre en otros países, la legislación penal de los mismos no contiene normas al respecto.

En concreto, los códigos penales de las entidades federativas, que sí prevén penas en los casos de calumnias, injurias, o difamaciones (doce, de treinta y dos), son: Baja California (artículos 185 a 191); Baja California Sur (artículos 336 a 343); Campeche (artículos 244 a 249); Colima (el delito de difamación fue eliminado en 2013; permanece 
Este obra forma parte del acervo de la Biblioteca Jurídica Virtual del Instituto de Investigaciones Jurídicas de la UNAM www.juridicas.unam.mx

la calumnia en el artículo 221); Guanajuato (artículos 188 a 190); Hidalgo (artículos 191 a 202); Nayarit (artículos 294 a 297): Nuevo León (artículos 342 a 347); Sonora (artículos 284 a 291); Tabasco (artículos 166 a 174); Yucatán (artículos 293 a 300); Zacatecas (artículos 272 a 284). ${ }^{123}$

Por ello, habrá que construir a veces, sobre experiencias extranjeras, experiencias en las que no faltan materiales. Cuando hablamos de libertad de expresión durante las elecciones, estamos hablando de dilemas que se presentan siempre que hay un proceso de ese tipo. No existirá más problema que el de conocer críticamente dichas realidades y las soluciones que en ellas se proponen, para adaptarlas a la mexicana que ya sabemos que es muy peculiar.

Allí podremos encontrar algunas guías, nunca totalmente seguras, para abordar los conflictos propios pero el examen de ellas habrá de hacerse con detalle, y siempre teniendo en cuenta que se proyectan sobre circunstancias muy diferentes. Nada que ver con algunos ejercicios de derecho comparado que desconectan las normas extranjeras de las bases que las explican. No es tarea fácil, sin embargo, es sin duda enriquecedora. Esperamos que este modesto trabajo sea un ejemplo de ello, porque este ambicioso objetivo era el nuestro. Somos conscientes de que, a lo sumo, lo hemos alcanzado de una manera parcial. Será el lector el que deba decir si el resultado le es en alguna medida útil.

\section{FUENTES CONSULTADAS}

ALCOCER VILLANUEVA, Jorge, “Evaluación integral del modelo de acceso a radio y televisión en materia electoral", Revista Mexicana de Derecho Electoral, núm. 4, 2013.

APT, Benjamín L., "On the Right to Freedom of Expression in the European Union”, 4 Columbia Journal of European Law69, 1998.

ARNALDO ALCUBILLA, Enrique, “La administración electoral como administración de garantía de las elecciones libres", en PASCUA MATEO, Fabio (dir.), Estado democrático y elecciones libres: cuestiones fundamentales de derecho electoral, Asamblea de Madrid, Thomson-Civitas, 2010.

Astudillo, César et al., "La libertad de expresión y sus principales manifestaciones en el contexto de la democracia electoral mexicana", Revista Mexicana de Derecho Electoral,

${ }^{123}$ Debo este dato, de nuevo, a Yessica Esquivel. 
Este obra forma parte del acervo de la Biblioteca Jurídica Virtual del Instituto de Investigaciones Jurídicas de la UNAM www.juridicas.unam.mx

núm. 4, 2013.

BARENDT, Eric, Freedom of Speech, Clarendon Press, Oxford, 2007.

BilBAO UBiLlos, Juan María, “La excarcelación tenía un precio: el Tribunal enmienda la plana al legislador (comentario de la STC 136/1999, en el caso de la Mesa Nacional de HB)", Revista Española de Derecho Constitucional, núm. 58, 2000.

Bustos GisBeRT, Rafael, “Los derechos de libre comunicación en una sociedad democrática (artículo 10 CEDH), en GARCíA ROCA, J. y SANTOLAYA, P. (coords.), La Europa de los derechos: el Convenio Europeo de Derechos Humanos, 2da. ed., Madrid, Centro de Estudios Políticos y Constitucionales, 2009.

Calleja GutiérRez, Aleida Elsi et al., "Perspectivas y evolución del modelo de comunicación político electoral", Revista Mexicana de Derecho Electoral, núm. 4, 2013.

CANTÚ, Jesús, et al, "Conexión entre medios de información y preferencias electorales", Revista Mexicana de Derecho Electoral, núm. 4, 2013.

CARBoneLL, Miguel, La libertad de expresión en materia electoral, México, TEPJF, 2008.

COSTA MARTínez, Joaquín, Oligarquía y caciquismo como la forma actual de gobierno en España: urgencia y modo de cambiarla, Madrid, Biblioteca Nueva, 1998, 1901.

De JUAN AsEnjo, Oscar, La constitución económica española, Madrid, CEC, 1984.

DraGo, Guillaume, Contentieux constitutionnel français, 3ra. ed., París, PUF, 2011.

DWORkIN, Ronald, Taking Rights Seriously, 3ra. ed., Londres, Duckworth, 1981. La versión española es, Los derechos en serio, Barcelona, Ariel, 1984.

Entrena Cuesta, Ramón, "Justicia electoral", en Pascua Mateo, Fabio (dir.), Estado democrático y elecciones libres: cuestiones fundamentales de derecho electoral, Asamblea de Madrid, Thomson-Civitas, 2010.

ESQUIVEL, Yessica, Libertad de expresión en campaña electoral, manuscrito inédito, facilitado por la autora, 2013.

Falcón y TelLA, María José, Equidad, Derecho, y Justicia, Madrid, Ramón Areces, 2005.

——— Equity and Law, Martinus Nijhoff, Leiden-Boston, 2008.

FARRÉ LóPEZ, Pedro, El derecho de rectificación. Un instrumento defensa frente al poder de los medios, La Ley, Las Rozas de Madrid, 2008. 
Este obra forma parte del acervo de la Biblioteca Jurídica Virtual del Instituto de Investigaciones Jurídicas de la UNAM www.juridicas.unam.mx

DOI: http://dx.doi.org/10.22201/iij_24487910e_2016.9.10094

FAVOREU, Louis et al., Droit constitutionnel, 6a. ed., París, Dalloz, 2003.

FERNÁNDEZ-MiRANDA CAMPOAMOR, Carmen, La verificación de poderes, Madrid, UNED, 1987.

FORMERY, Simon-Louis, La Constitution Commentée, 12a. ed., París, Hachette, 2008-2009.

FrosinI, Tommaso Edoardo, Le votazioni, Laterza, Roma-Bari, 2002.

GARCÍA ROCA, Javier, “Del compromiso internacional de los Estados de organizar elecciones libres al derecho de sufragio de los ciudadanos (artículo 3 P1)", en GARCía RocA, J. y SANTOLAYA, P. (coords.), La Europa de los derechos: el Convenio Europeo de Derechos Humanos, 2da. ed., Madrid, Centro de Estudios Políticos y Constitucionales, 2009.

GarCía Soriano, María Vicenta, Elementos de derecho electoral, Valencia, Tirant lo Blanch, 1999.

- - Jueces y magistrados en el proceso electoral, Madrid, CEPC, 2000.

GonZÁlEZ RIVAS, Juan José, “Análisis de los recursos de amparo electorales a la vista de la jurisprudencia constitucional", en PASCUA MATEO, Fabio (dir.), Estado democrático y elecciones libres: cuestiones fundamentales de derecho electoral, Asamblea de Madrid, Thomson-Civitas, 2010.

HARDT, Sacha, Parliamentary Immunity, Intersentia, Cambridge, Antwerp, Portland, 2013.

JARASS, Hans D., Charta der Grundrechte der Europäische Union. Kommentar, 2da. ed., München Beck, 2013.

JARAMillo, Juan, "Los órganos electorales supremos", en NoHLEN, Dieter et al., (comp.), Tratado de derecho electoral comparado de América Latina, 2a. ed., San José, Instituto Interamericano de Derechos Humanos, 2007.

JAN, Pascal, Le procès constitutionnel, París, L. G. D. J, 2010.

JUÁREZ GÁmIZ, Julio y BRAMBILA, José Antonio, “La publicidad política televisiva en el proceso electoral en México", Revista Mexicana de Derecho Electoral, núm. 4, 2013.

KraUze, Enrique, “La dictadura perfecta”, Letras Libres, 12 de noviembre de 2012.

LóPEZ GUERRA, Luis, Las campañas electorales en Occidente, Barcelona, Fundación Juan March-Ariel, 1977.

MANCISIDOR ATARAZ, Eduardo, La prerrogativa constitucional del inviolabilidad parlamentaria, Oñati, IVAP, 2009. 
Este obra forma parte del acervo de la Biblioteca Jurídica Virtual del Instituto de Investigaciones Jurídicas de la UNAM www.juridicas.unam.mx

MARTíN-RETORTILLO BAQUeR, Lorenzo, “Los derechos electorales a la luz de la jurisprudencia del Tribunal Europeo de Derechos Humanos", en PASCUA MATEO, Fabio (dir.), Estado democrático y elecciones libres: cuestiones fundamentales de derecho electoral, Asamblea de Madrid, Thomson-Civitas, 2010.

MARTínez RuANo, Pedro, Antecedentes históricos de la administración electoral, Almería, Universidad de Almería, 2008.

MATHEUS FeRnÁnDEZ, Juan Miguel, La disciplina parlamentaria, Zaragoza, Fundación Manuel Giménez Abad, 2013.

MAUNZ, Theodor, "Comentario al artículo 41", en MAUnZ-DÜRIG-HeRZOG-SCHOLZ Grundgesetz Kommentar, München, C. H. Beck, 1960.

Merino, Mauricio y Baños, Marco Antonio, "El servicio electoral profesional", en NOHLEN, Dieter y otros (comp.), Tratado de derecho electoral comparado de América Latina, 2da.ed., San José, Instituto Interamericano de Derechos Humanos, 2007.

MIR PUIG, Santiago, Derecho penal. Parte general, 7a. ed., Barcelona, Reppertor, 2006.

MORRIS, Caroline, Parliamentary Elections, Representation and the Law, Hart, Oxford and Portland, 2012.

Muñoz Conde, Francisco y García Arán, Mercedes, Derecho penal. Parte general, 7a. ed., Valencia, Tirant lo Blanch, 2007.

NOHLEN, Dieter, Sistemas electorales del mundo, Madrid, CEC, 1981.

PASCUA MATEO, Fabio, La administración electoral, Madrid, INAP, 2007.

- E El control de las elecciones, Madrid, Civitas/Thomson, 2009.

——— “La unidades de la administración gubernativa de apoyo técnico al proceso electoral", en PASCUA MATEO, Fabio (dir.), Estado democrático y elecciones libres: cuestiones fundamentales de derecho electoral, Asamblea de Madrid, ThomsonCivitas, 2010.

——— "La revisión administrativa de los actos de la Administración electoral", en PASCUA MATEO, Fabio (dir.), Estado democrático y elecciones libres: cuestiones fundamentales de derecho electoral, Asamblea de Madrid, Thomson-Civitas, 2010. 
Este obra forma parte del acervo de la Biblioteca Jurídica Virtual del Instituto de Investigaciones Jurídicas de la UNAM www.juridicas.unam.mx

Pastor Albaladejo, Gema, Calidad de la democracia y Administración Electoral, Madrid, Congreso de los Diputados, 2011.

Pieroth, Bodo, "Comentario al artículo 41", en JARASS/PIEROTH, Grungesetz für die Bundesrepublik Deutschland. Kommentar, 2da. ed., München, C. H. Beck, 1992.

Rallo LombarTe, Artemi, Garantías electorales y Constitución, Madrid, CEPC, 1997.

RECODER VALLINA, Tatiana, “Las campañas en período electoral: la campaña electoral y la campaña institucional", en PASCUA MATEO, Fabio (dir.), Estado democrático y elecciones libres: cuestiones fundamentales de derecho electoral, Asamblea de Madrid, Thomson-Civitas, 2010.

ROBLEDo Rincón, Eduardo, La democratización en México, ¿cambio o evolución del régimen?, Tesis doctoral inédita defendida en la Facultad de Derecho de la Universidad Complutense de Madrid, 2001-2012.

SÁNCHEZ MuÑOz, Oscar, La igualdad de oportunidades en las competiciones electorales, Madrid, CEPC, 2007.

SANTOLAYA MACHettI, “La administración electoral”, en Álvarez Conde, Enrique (coord.), Administraciones públicas y Constitución: reflexiones sobre el XX aniversario de la Constitución española de 1978, Madrid, INAP, 1998.

_-_ Procedimiento y garantías electorales, Civitas-Thomson, Cizur Menor, 2013.

SONNLEITNER, Willibald et al., "La paradoja mexicana: de la evaluación de la calidad técnica de las elecciones de 2012, al debate sobre la calidad del voto y a la cuestión de la legitimidad democrática", Revista Mexicana de Derecho Electoral, núm. 4, 2013.

TORRES MURO, Ignacio, “La libertad de expresión en las campañas electorales y sus límites. Propaganda negativa. Problemas y controles"; en Ríos VEGA, Luis Efrén (coord.), Tópicos contemporáneos de derechos políticos fundamentales, Madrid, Dykinson, 2010. 
Este obra forma parte del acervo de la Biblioteca Jurídica Virtual del Instituto de Investigaciones Jurídicas de la UNAM www.juridicas.unam.mx https://biblio.juridicas.unam.mx/bjv

https://revistas.juridicas.unam.mx/

DOI: http://dx.doi.org/10.22201/iij.24487910e.2016.9.10094

VARela ORTEGA, José, Los amigos políticos. Partidos, elecciones y caciquismo en la Restauración (1875-1900), Madrid, Alianza Universidad, 1977.

VARGAS LloSA, Mario, “La dictadura perfecta”, sección “Tribuna”, El País, 1 de junio de 1992.

VinCENT, Jean Marie y WeBer, Max, "La metodología de Max Weber", “Fundamentos metodológicos de la sociología", Barcelona, Anagrama, 1972.

WEBER, Max, “La <<objetividad>> cognoscitiva de la ciencia social y de la política social”, en WEBER, Max, Ensayos sobre metodología sociológica, Buenos Aires, Amorrortu, 2001; e. o. 1904.

——__Economía y Sociedad, México, Fondo de Cultura Económica, 1992; e. o. 1992. 